\title{
Flash Flood Risk Estimation of Wadi Yutum (Southern Jordan) Watershed Using GIS Based Morphometric Analysis and Remote Sensing Techniques
}

\author{
Yahya Farhan, Omar Anaba \\ Department of Geography, University of Jordan, Amman, Jordan \\ Email: Yahyafarhan2100@outlook.com
}

Received 7 March 2016; accepted 26 April 2016; published 29 April 2016

Copyright (C) 2016 by authors and Scientific Research Publishing Inc.

This work is licensed under the Creative Commons Attribution International License (CC BY). http://creativecommons.org/licenses/by/4.0/

(c) (i) Open Access

\begin{abstract}
Flash flood disasters associated with heavy rainstorms are common in dry lands of Jordan. This causes inestimable damage to life and infrastructure. In the present investigation, flash floods were assessed in Wadi Yutum watershed, southern Jordan. Assessment was conducted using remote sensing and GIS techniques, combined with geological and geomorphic field data to evaluate the probability of flooding risk spatially. Two methods were used to assess the flooding risk for seventeen sub-basins of W. Yutum: the morphometric ranking method; and El-Shamy's approach. Both methods utilized twenty morphometric parameters of paramount interest for flash flood risk estimation. The results achieved based on the two methods enabled identification of sub-basins with a high potential of flash flooding, and served to reveal the common sub-basins falling under each category of flooding risk. Morphometric analysis and GIS were employed to produce flood hazard maps which displayed sub-basins exposed to harmful flooding in Wadi Yutum. The adopted methodology can be applied to estimate flooding risk in other comparable watersheds and region in Jordan. Further, preparedness measures can be proposed in a timely manner in order to minimize destructive flood effects.
\end{abstract}

\section{Keywords}

Flash Floods, Morphometry, ASTER DEM, Drylands, Wadi Yutum, Jordan

\section{Introduction}

The vulnerable and stressful conditions of arid southern Jordan, including Wadi Yutum watershed and the lower

How to cite this paper: Farhan, Y. and Anaba, O. (2016) Flash Flood Risk Estimation of Wadi Yutum (Southern Jordan) Watershed Using GIS Based Morphometric Analysis and Remote Sensing Techniques. Open Journal of Modern Hydrology, 6, 79-100. http://dx.doi.org/10.4236/ojmh.2016.62008 
Wadi Araba, impose careful site selection for urban and rural land use development to assure sustainability [1]-[4]. The long intervals between high-magnitude, low frequency flood events, and the lack of hydrological data have often led the planners to ignore, or pay little attention to the fluvial processes and the associated geomorphic hazards, i.e., flash floods, gully erosion and abundant sediment supply. Over the last four decades, there have been a notable number of applied geomorphic studies carried out in arid areas worldwide, thus enhancing geomorphic techniques which can be adopted to avoid destructive hazards, and to improve levels of awareness regarding floods geomorphology and the role of applied geomorphic surveys and information in planning processes [2] [5]-[9]. Past experience from arid coastal cities such as Aqaba and other comparable cities, i.e. Eilat at the opposite corner of the Gulf of Aqaba [4] [10], Gulf of Suez, Red Sea, and Sinai Peninsula, Egypt [11]-[18] indicates that flash floods are considered the most recurrent disaster recorded over the last three decades (1981-2011), not only in drylands of Jordan and Egypt, but in the entire Middle East [19]. Unplanned urban growth has frequently resulted in heavy disturbance of land surface and natural drainage. In the light of poor perception of floods hydrology and the associated fluvial processes, and the prominent lack of adequate and efficient hydraulic structures, the Aqaba area was exposed to additional serious floods initiated by Wadi Yutum, and other wadis descending from the granite mountains overlooking lower Wadi Araba and the Gulf of Aqaba. Recent flood monitoring [4] demonstrates that "a small flood occurred every few years, more rarely a large one, and perhaps a truly catastrophic flood once in a few decades". However, the hydro-geomorphic characteristics of flash floods in the Aqaba area are poorly understood due to the lack of long-term monitoring of fully instrumented arid watersheds and paleoflood studies as compared with Eilat on the opposite NW corner of the Gulf of Aqaba. Furthermore, long-term hydro-meteorological data are not available. Therefore, due to difficulties in predicting flash floods, planning adjustment to flooding risk, emergency and evacuation plans are of high priority, where Aqaba city has been almost disrupted by a flash flood of low or medium magnitude every two years in the last past decade [20] [21]. Accordingly, the spatial distribution of land use categories, the expanding of residential areas across wadi floors, economic and life losses are expected to increase due to continuous exposure of assets and population to risk. An increase in frequency and intensity of heavy rainfall, and probably certain effects of climatic change [22]-[24], will cause an increase in flash floods occurrences. The residential areas, the airport, the industrial zone, and the Aqaba-Amman highway (the most vital highway in Jordan) across Wadi Yutum, are all located in flood-prone areas on the apex, middle and toe parts of the alluvial fans of Wadi Yutum and other wadis to the north and south of Aqaba [21]. Such conditions are a particularly challenging task at present and will remain so in the future [8] [21]. Unfortunately, all previous plans for the Aqaba area [25]-[27] suffer from a prominent lack of appreciation of the morpho-hydrological setting of the bajada at the lower W. Araba including the W. Yutum watershed, and other wadis north and south of W. Yutum. Limited or even poor perception of flash flood disasters among engineers, planners, managers, developers and the inhabitants as a whole is obvious in the Aqaba area. As Schick [28] stated over four decades ago, perhaps because of the "inexorable monotonous dryness", the dry land urban population does not expect and is usually not prepared for flood hazards. Often, urban expansion and development is conducted in complete ignorance of the potential threat of flash flooding and the associated sediment discharge. Nevertheless, scattered hydrological studies/reports on flash floods have been carried out for W. Yutum [3] [20]-[21] [28]-[31]. These studies confirm that the Aqaba area has been exposed to recurrent flash floods since the 1950s, where low magnitude (5 - 7 year return periods), medium magnitude (20 - 25 year return periods), and high magnitude (50 year return periods) floods have been recorded. It is postulated that the northern parts of the Aqaba area are the terrain system most vulnerable to flash flooding hazard. Flash floods always have a significant negative impact on the city of Aqaba. It causes immense damage to lives and the infrastructure (i.e. residential areas, highway, roads, hydraulic structures) and coastal pollution. Therefore, since the city and the port of Aqaba are considered crucial to the Jordanian economy, the protection of the city/port from repetitive flooding is important to maintain future urban and economic development [21]. However, several physical factors contribute to the flooding problem, and influence flash flood severity in dry land urban centers. Among these factors are: morphological setting and site characteristics, topography and slope, drainage properties, available hydraulic structures, land cover, hydrology and climate (i.e. rainfall intensity and duration, water loss (evaporation and infiltration), drainage networks and orders, environmental processes and human interventions [11] [32]. It is not practical to conduct a flood hazard evaluation for large areas/watersheds from time to time based on field monitoring and measurements. Alternatively, remote sensing and GIS techniques coupled with geomorphometric and hydrologic parameters provide a rapid, low cost and efficient approach to determine areas of potential flooding, levels of risk, basins and sub- 
basins with similar susceptibility to flash flooding.

Watershed characteristics have been established in studies worldwide using conventional geomorphometric analysis methods. Geometric properties of drainage networks in relation to typology of stream networks, and quantitative analysis of linear, areal, shape and relief aspects of drainage basins were intensively addressed earlier [33]-[41]. Moreover, morphometric properties of drainage networks have been utilized to predict hydromorphic processes such as peaks of floods, sediment yields, and erosion rates [42]. The relationship between watershed morphometry and flooding impact has been explored thoroughly by Patton [42]. At present, delimitation of drainage basins, and calculation of morphometric parameters can be achieved using remote sensing tools DEMs, GIS software, and mathematical formulas elaborated by Strahler [34]-[36] [44]-[50]. Flooding susceptibility assessment for dryland watersheds was executed recently for various watersheds along the Red Sea Coast and the Gulf of Suez, Egypt, which are environmentally comparable to the Gulf of Aqaba, W. Yutum watershed and other wadis of lower wadi Araba [11] [12] [15]-[18] [51] [52]. Evaluation of periodic flash floods based on El-Shamy's model was carried out on dryland watersheds in the southern Red Sea coast of Egypt [15]. Furthermore, analysis of drainage basin morphometry was performed to assess flood prone areas utilizing El-Shamy's approach in western Saudi Arabia [53]. Similarly, Abdel-Lattif and Sherief [14] evaluated flash floods for two wadis (W. Sudr and W. Wardan, Gulf of Suez, Egypt) based on morphometric analysis and El-Shamy's approach. It is obvious that previous investigations employed either El-Shamy's model to assess flash floods risk or, combined this with elaborated morphometric analysis methods developed and employed successfully for flash flood risk estimation. By contrast, Youssef et al. [12] developed a GIS morphometric analysis approach to estimate levels of flash flood risk for sub-watersheds within the main watershed. The results were compared with those achieved through the application of El-Shamy's model. It can be concluded that both methods are rational for flash flood risk assessment. El-Maghraby et al. [54] employed morphometric analysis to evaluate the flash flood hazard of W. Al Hamd sub-basins, western Saudi Arbia. Nine morphometric parameters which have a direct influence on flooding were selected and analyzed in relation to flash floods. These parameters are: watershed area $(A)$, drainage density $\left(D_{d}\right)$, stream frequency $\left(f_{s}\right)$, shape index $\left(\mathrm{S}_{\mathrm{i}} \%\right)$, slope index $\left(S_{w}\right)$, relief ratio $\left(R_{f}\right)$, ruggedness number $\left(R_{n}\right)$, texture ratio $\left(R_{t}\right)$, and weighted mean bifurcation ratio $\left(\mathrm{WMR}_{\mathrm{b}}\right)$. A hazard scale number starting with 1 (lowest) to 5 (highest) has been assigned to all parameters. Calculation and spatial distribution of hazard degrees have been discussed in detail based on Davis [55].

\section{Description of the Study Area}

\subsection{Geology and Geomorphology}

Wadi Yutum and the Aqaba area are located in southern Jordan, east of the Gulf of Aqaba and lower Wadi Araba. The study area lies between $29.15 \mathrm{~N}$ to $30.01 \mathrm{~N}$ latitude and $34.58 \mathrm{E}$ to $35.52 \mathrm{E}$ longitude (Figure 1(a) and Figure 1(b)). The Aqaba area comprises the northern edge of the Arabian plate east of the lower W. Araba fault and the Gulf of Aqaba [56]. The exposed rocks sequence consists mainly of igneous rocks (pre Cambrian)which represent the granite horst overlooking lower W. Araba and the Gulf of Aqaba (Figure 2) [57] [58]. The granite horst/inselberg landscape west of Quweria-Ram area is composed of aplite-granite, granodiorite, and quartzdiorite with an age ranging between $585+8 \mathrm{Ma}$ [59]. Granodiorite and aplite granite are exposed at the base of sandstone inselberg (the erosional residuals) west of Jebel Rum to form a minor horizontal bench, or plinth at the igneous/sandstone contact [57]. Slopes underlain by these rocks range from $30^{\circ}$ to $40^{\circ}$, while slopes overlying sandstones are almost near-vertical. To the west of Quweira, remnants of large strips of the pre-sandstone peneplain were preserved. The granite is highly weathered, and extensively intruded by dykes. Due to variations in the composition of granite [59] [60], dyke type and density [61], and the rate of weathering [62] topographic expression is varied, ranging from rugged mountainous terrain to undulating ridges and subrounded morphology [30].

The important landforms of the central part of W. Yutum watershed are the "cliffed sandstone inselbergs", which rise $800 \mathrm{~mm}$ above the playas and sand flats of the desert floor. To the north-east, the watershed is bounded by Ras En Naqb escarpment (200 - 350 m high), which is formed of Cretaceous limestone, shales, marls and Kurnub sandstones (Lower Cretaceous). It is believed that these strata originally extended over what is now the inselberg landscape although the original southern terminus is unknown. However, on the west side of the Dead Sea Rift, remnants of these strata are found clear down to the southern extreme of the Sinai Peninsula [36]. Landslides are active on Ras En Naqb escarpment following recurrent intense and heavy rainstorms, 


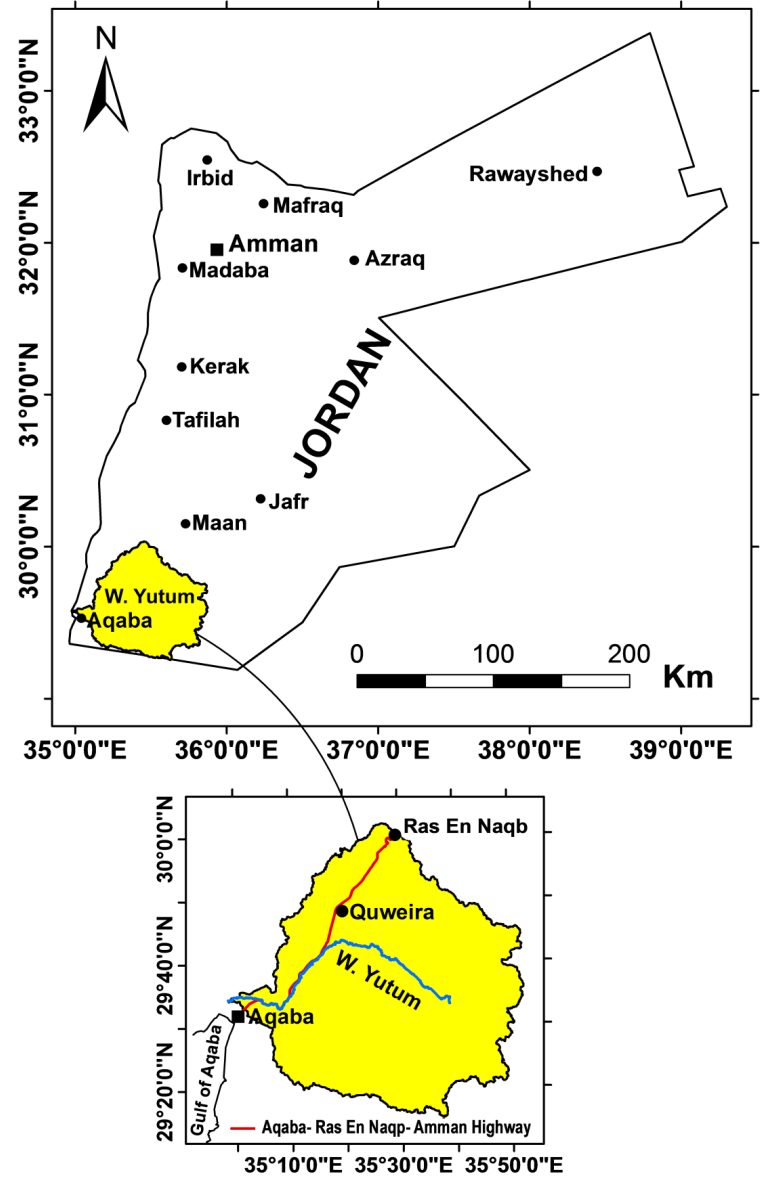

(a)

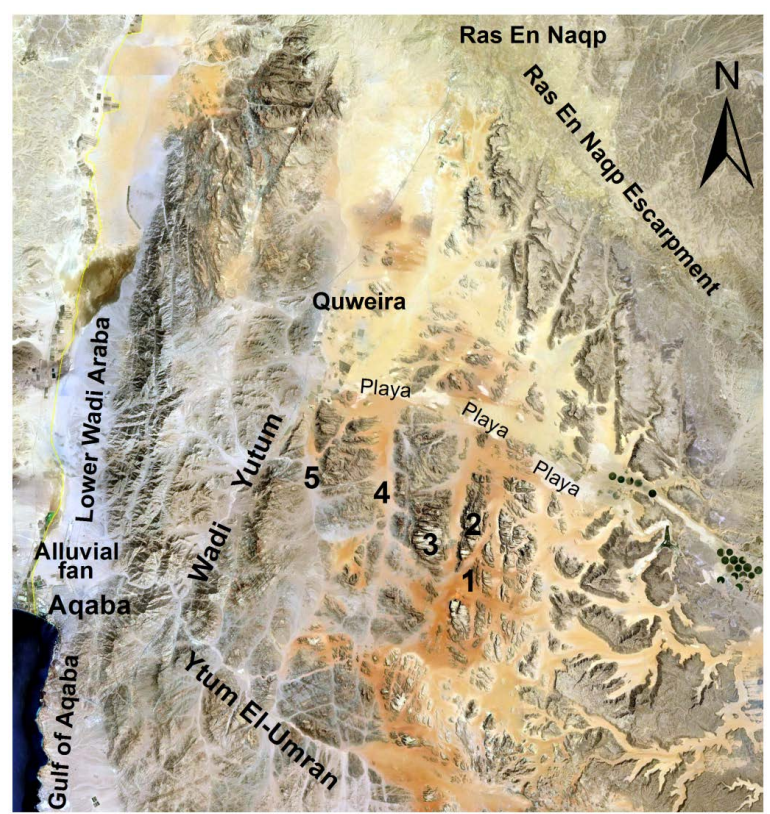

1-W.Ishrin 2-J.Ishrin 3-J.Rum 4-W.Rumman 5-W.Marsad

(b)

Figure 1. (a) The study area; (b) Google Earth Pro Image (2013) for W. Yutum watershed. 


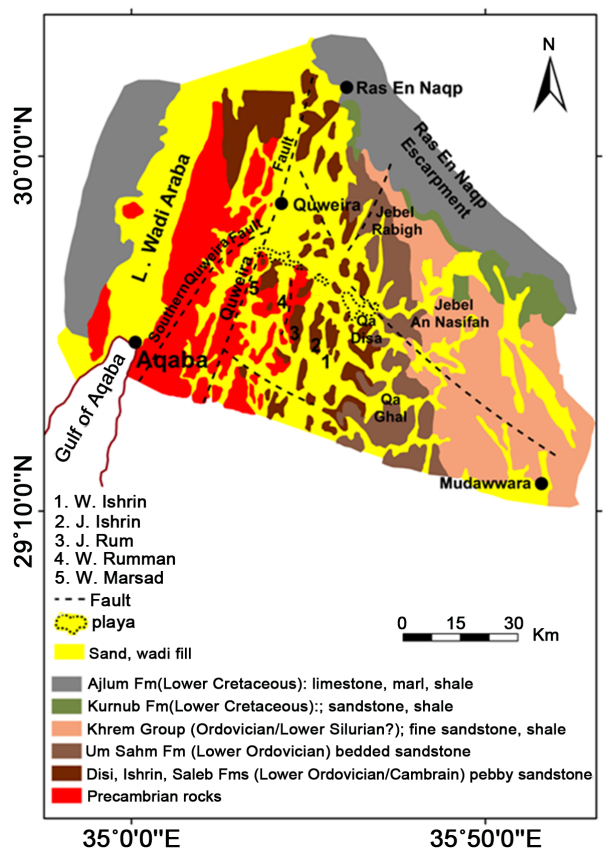

Figure 2. Geology of W. Yutum watershed.

and occasionally have threatened the Amman-Aqaba vital highway. Oversteepening of slopes due to highway/ road construction, fluvial erosion and differential weathering encourage rock falls, rock slides, and slumping from heavily jointed limestone beds. Percolation of water from relatively abundant precipitation over Ras En Naqb (140 mm annually), towards impervious marl, shale, and clay of the nodular limestone unit reduce the shear strength of the materials, thus activating landslides. At the base of the escarpment, pure white Ordovician sandstone with scattered quartz granules and pebbles is exposed (Figure 2). The sandstone strata dip gently to the east; consequently, younger sandstone units are exposed in succession on the top of inselbergs as one proceeds to the east. Although the total thickness of sandstone units in S-W Jordan is about $900 \mathrm{~m}$, no complete section can be seen at one site. The sandstones are fairly weakly cemented, a property which aids in their weathering and erosion along joints and fissures [63].

Three types of inselbergs at the central part of W. Yutum around Quweira exist (Figure 3). These can be differentiated based on slope morphology and slope categories [64]. The first type is of relatively gentle slopes (up to $40^{\circ}-45^{\circ}$ ), with numerous steps a few meters high and benches covered by debris. The second type is steep-side inselbergs, with cliffs towering above the base by as much as $110-150 \mathrm{~m}$, often with a very sharp piedmont angle, little talus, and rather flattish summit surfaces. The slopes are subjected to cavernous weathering and tafoni formation. The third type is a dome-like hill, with steeply sloping sides, and convex in profile. It is associated with iron-depleted beds of pure white sandstone, and it gives rise to locally more rounded hillslope morphology within the steep-sided inselbergs with sharp breaks, and steeped slope morphology.

The bajada of the lower W. Araba, is composed of several large coalescing alluvial fans deposited by W. Yutum and other wadis (to the north and south of it), at the foot of the granite mountains. The mean slope recorded ranges between $4^{\circ}$ and $5^{\circ}$. The fan surface area is found to be proportional to the drainage basin and because of the greater sediment inputs deposited at the mouth of the wadi. Alluvial fans of the bajada revealed periods of heavy rains or flash floods with a resultant debris flow and stream flood deposition [65]. The alluvial fans of the lower W. Araba were terminated with Qa'ed Dafiya (2 km width and $12 \mathrm{~km}$ length) at the western margin of the bajada.The southernmost sector of the W. Yutum huge fan directs its distributaries towards Aqaba City.

To the west of Ras En Naqb and the playa system, and east of Quweira, the W. Yutum major course (although almost always dry) cuts through the granite horst and drains into lower Wadi Araba just north of Aqaba. The wadi is separated from the playas by sand sheets. Apparently, with the dominance of the hyper-arid climate, there is rarely enough water collected in the playas to drain out into the wadi. Yet in a gross sense, Wadi Yutum is the ultimate drain of the entire inselberg region north of the Saudi border drainage divide, while the playas in this regard serve as intermediate base levels [62]. 


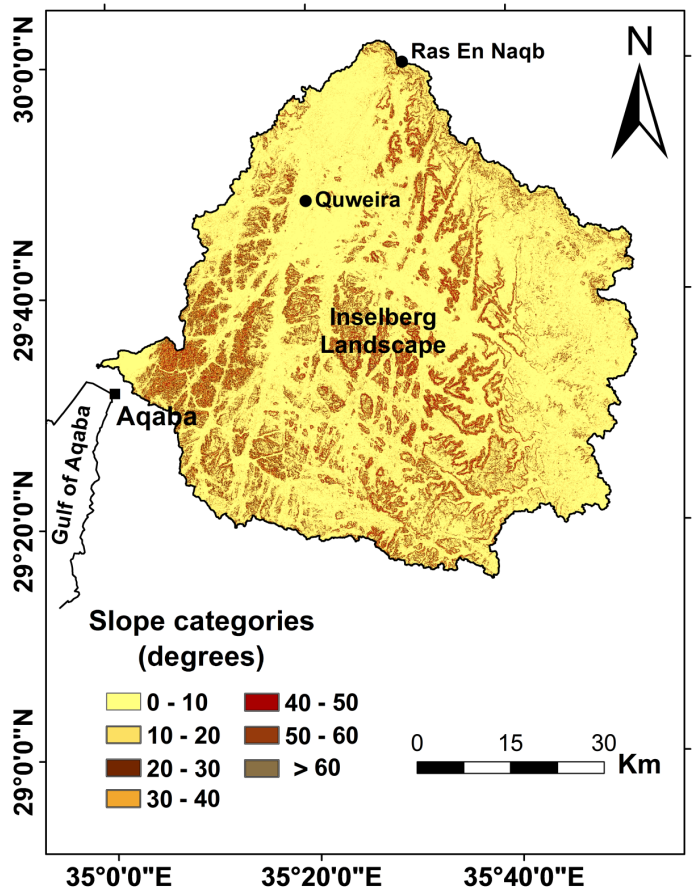

Figure 3. Slope categories.

Structurally, W. Yutum watershed is characterized by normal faults and vertical joint sets. Lloyd [66] distinguished two major groups of faults: one trending roughly N-S (or more specifically $5^{\circ}$ to $20^{\circ} \mathrm{E}$ of $\mathrm{N}$ ), the other trending NW-SE. The Quweira fault with a large vertical down throw of up to $600 \mathrm{~m}$ (Figure 2), and a fault running down of W. Marsad, with vertical offset of 400 m exemplify the former group of faults. These two adjacent faults form a graben, and similar features occur among smaller displacement faults further east. NWtrending faults give rise to having minor offsets, as stated by Heimbach and Meiser [66] based on geoelectrical resistivity survey. The most prominent $\mathrm{NW}$-trending fault is the Hiswa fault with a downthrow of $300 \mathrm{~m}$. It runs along a wadi/playa system southeast of Qa' Disa. Several graben-forming normal faults in the Quweira area are hidden beneath unconsolidated sand sheets [62] [63]. Lloyd [66] also reported the presence of two major joint directions in the area, corresponding roughly with the two main fault directions. Numerous faults were also mapped by Bender [68] along part of the Ras En Naqb escarpment and belong to the NW-trending category. The alluvial fan of W. Yutum endangers directly a quarter of the unplanned dwelling zone. The steep overall slope of the fan $\left(4^{\circ}-5^{\circ}\right)$ facilitates flood waters to reach any point along an $8 \mathrm{~km}$ circumference of the fan sector, and together with smaller fan adjoining to the north, creates flooding hazards for the Aqaba airport with its $3 \mathrm{~km}$ long runway. The high relative relief and bare granite facilitate the background for extremely destructive flooding in the downstream urbanized area developed between the granite horst front and the inland Qa's and sabkhas with a large damage potential [4].

\subsection{Climatic Conditions and Flooding Problems}

The climate of W. Yutum is hyper-arid in the Aqaba-Quweira, and Ras en Naqb areas, with a slight variation between these areas in terms of rainfall amounts and temperature. The climate is hot, dry and arid in the Aqaba area (lower W. Yutum) and Quweira (middle W. Yutum), and cold, dry and arid on the crest of Ras En Naqb (upper W. Yutum). Due to variation in topography, the average annual rainfall varies from $37 \mathrm{~mm}$ at Aqaba, to $65 \mathrm{~mm}$ at Quweira town (800 m a.s.l.), to $140 \mathrm{~mm}$ at Ras En Naqb village (1573 m a.s.l., Figure 4). It has been concluded by Lloyd [66] that tributaries of W. Yutum watershed have about five to seven runoff producing storms per year, which last no more than a few hours, and are capable of producing serious flash floods. Seventy percent of rainfall events occur between December and January. Furthermore, single storm rainfall totals can be very high and may far exceed the mean annual rainfall; thus, rainfall intensities are very high. Rainfall is often of the convective type with some effect of orography [28] [68]. The convective rains usually occur during warm 


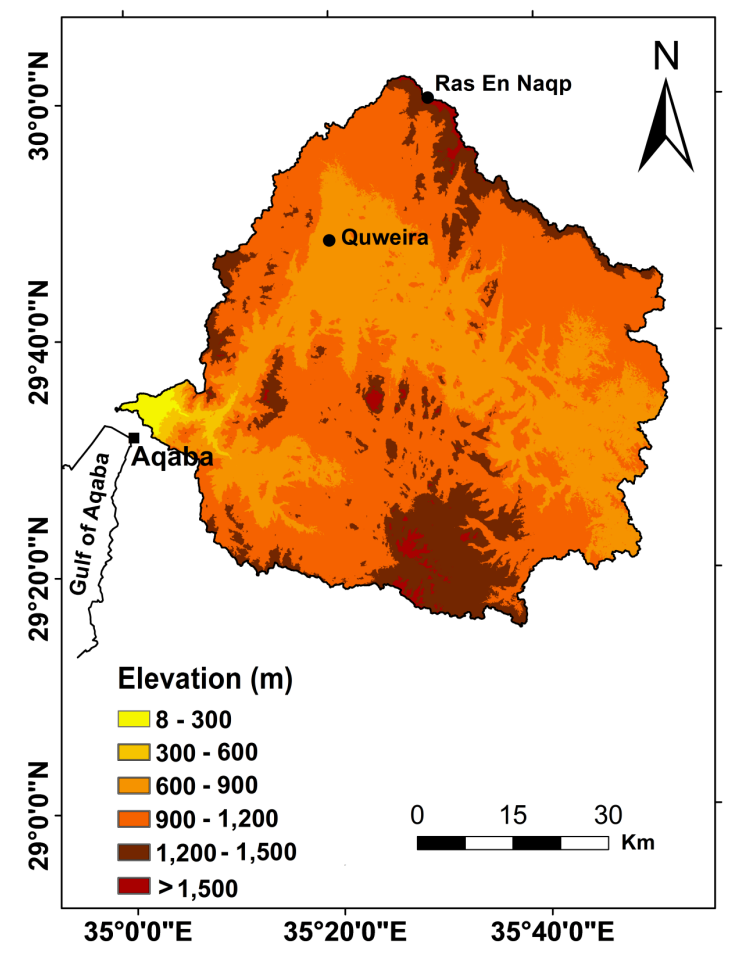

Figure 4. Elevation (m).

months such as October, March and April, and are characterized by intense rainfall of short duration similar to that which occurred, for example, in 1991, 1993, 1994, 2006, 2010, 2012, 2013, 2014, and 2015 respectively ( mainly based on field observations, local news papers, and published work, i.e. reference [20]). A localized pattern of rainfall is also characteristic of $\mathrm{W}$. Yutum catchment, where rainfall might affect limited areas only. Sixty percent of the total rainfall comes from spotty rain, where spottiness of rainfall is clearly pronounced in the fall and spring thunderstorms [69], which occur at an annual average of four events/year in southern Jordan [70]. Most of the annual rainfall may fall during one event and concentrated occasionally in but a few hours, or less. Accordingly, rainfall intensity is predicted to be high and it may reach $120 \mathrm{~mm} / \mathrm{h}$ for $10 \mathrm{~min}$ [20].

Since the 1950's, the Aqaba weather station has recorded great events of maximum rainfall intensities over 24 hrs. Examples are: 34 mm (1953), 27 mm (1955), 36.3 mm (1963), 32.8 mm (1966), 65 mm (1975), $42.5 \mathrm{~mm}$ (1980). Such figures show that high rainfall intensity occasionally resulted in severe flash flooding associated with large sediment load. During the storm of 11 March 1966 for example, Aqaba recorded $37 \mathrm{~mm}$, Ras En Naqb $71.2 \mathrm{~mm}$, Ma'an $39 \mathrm{~mm}$, and the highlands west of Ma'an received $60 \mathrm{~mm}$ fall in 4 hrs, with an intensity of $15 \mathrm{~mm}$, Ras En Naqb $140 \mathrm{~mm}$ and Ma'an $40 \mathrm{~mm}$. The flash flood of the 11 March 1966 rainstorm is categorized as a 50-year return period. The rainfall recorded during the thunderstorm of May 2014, was high in southern Jordan generally (in Tafila for example $80 \mathrm{~mm}$, in Shawbak $45.6 \mathrm{~mm}$, Wadi Musa and Petra $32.8 \mathrm{~mm}$, and in Ma'an $24 \mathrm{~mm}$ ), all of them are located north of the W. Yutum watershed. By contrast, Aqaba City received only $3.6 \mathrm{~mm}$ in $20 \mathrm{~min}$, thus rainfall intensity was high and recorded $13 \mathrm{~mm} \cdot \mathrm{hr}^{-1}$ in $10 \mathrm{~min}$. It can be concluded that Aqaba City, the Amman-Aqaba highway, the towns and villages, and irrigated farms across W. Yutum catchment have been subjected to flash floods several times. The frequency of flash floods has increased recently (almost every year in the Aqaba area and lower W. Yutum) and this has caused serious damage to properties, infrastructure, loss of life, residential areas, roads, and brought hardship for the residents of Aqaba.

In the present investigation, two methods of flash flood risk assessment have been employed. The first method is elaborated by El-Shamy [11] for assessing the susceptibility of sub-basins to flash flooding. The second method was formulated to estimate the degree of flooding risk based on morphometric analysis [12]. Two flood hazard risk map layers were generated for the seventeen sub-basins of W. Yutum based on each method. A third map was then compiled by integrating the result of flood hazard risk mapping achieved from both methods in order to assess the correlation if any, between the produced maps, and to explore the common hazardous flood- 
ing categories that may be found between the sub-basins.

The objective of this research is to:

1) Conduct morphometric analysis for the seventeen sub-basins within Wadi Yutum,

2) Generate flood hazard maps based on El-Shamy’s approach and the morphometric ranking method, to demarcate the sub-basins with low, intermediate, and high flooding susceptibility,

3) Identify the sub-basins which are expected to endanger the Aqaba area, the Amman-Aqaba highway, the Bedouin-rural settlements, and the irrigated farm across W. Yutum watershed.

4) Provide significant information which can help in planning adjustment with flood hazards, and to construct efficient flood prevention structures [71]-[74].

\section{Materials and Methods}

Topographic maps with a scale 1:50,000 (20 m contour interval) were provided by the Royal Jordanian National Geographic Centre (RJNGC). Adigital elevation model (DEM) is utilized to acquire and calculate morphometric parameters for the entire W. Yutum watershed and the seventeen sub-basins. The ASTER DEM (30 m spatial resolution) is provided on line for free to all users, and available in GeoTIFF format with geographical coordinates. It has a mesh size of 1 arc-second posting [75]. The elevation error of the DEM is found to be $+7.4 \mathrm{~m}$ for forest land cover, and $-0.7 \mathrm{~m}$ for bare land (such as Ras En Naqb, or the present study area), while the horizontal error is reported to be East/West shift of -0.13 arc-seconds and North-South shift of 0.19 arc-seconds when compared to the 10-m mesh DEM produced by the Geographical Survey Institute (GSI) of Japan [76]. It can be concluded that ASTER DEM is utilized worldwide in morphometric analysis research. The Arc GIS ve.10.1 software along with the available tools (mainly the Spatial Analyst extension) was employed to derive the drainage networks, mophometric parameters, and to generate different related maps (i.e. slope categories, elevation, etc.). The ArcHydro tool was also used to delineate the watersheds and stream networks of the study area. The extraction process passes through different steps discussed in detail in [77]. Geological maps of scale 1:250,000 [68] [78], scale 1:100,000 [58] [79], scale 1:500,000 [80] and 1:50,000 [81], and LANDSAT ETM+ (30 m spatial resolution, dated 2010) were employed to:

1) distinguish various igneous rock, sandstones, carbonate rocks and Quaternary materials, faults and major joints affected the study area,

2) outline landform features of W. Yutum watershed and to verify drainage networks derived from ASTER DEM, and

3) understand the terrain units in the bajada of lower W. Araba, inselberg landscape and Ras en Naqb escarpment in the study watershed. Additional geomorphic and hydrographic information were achieved during field observation.

These data are geo-referenced to the UTM coordinate system (WGS 1984 , Zone $36^{\circ} \mathrm{N}$ ) based on 1:50,000 topographic maps using Arc GIS. Areas affected by recent flash floods and expected to be exposed to future flooding were field inspected. Arc GIS 10.1 and ASTER DEM were employed to generate and digitize drainage networks for W. Yutum watershed and the seventeen sub-basins (Figure 5 and Figure 6) which impose serious hazards for the residents, infrastructure facilities, the Aqaba-Amman highway, roads, and economic activities in area. The stream order maps were compiled from flow direction map for each watershed using Stream Order tool. The stream ordering system used was based on Strahler's method [35] [36] [82] [83]. The entire W. Yutum watershed was found to be of seventh order.

\section{Flash Floods Analysis Methods}

Morphometric analysis for W. Yutum catchment and the seventeen sub-basing have been carried out within a GIS environment. The morphometric parameters which elucidate their impact on flash flooding behavior were calculated for the seventeen sub-basins using Arc GIS software, and the mathematical equations elaborated by Strahler [34]-[36] and illustrated in Table 1. The hydro-geomorphometric relations were employed to assess the degree of flooding risk based on the two methods noted above.

\subsection{Morphometric Ranking Method}

The first method was labeled the morphometric ranking method [12]. Two groups of morphometric parameters were used in the analysis and consist of 17 parameters. Three of these parameters are related to drainage network 


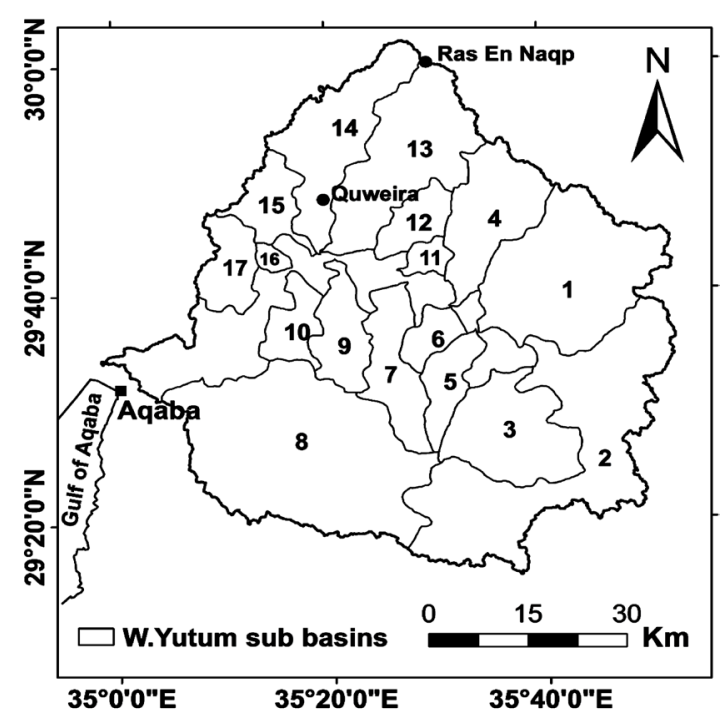

Figure 5. W. Yutum sub-basins.

Table 1. Calculation of morphometric parameters.

\begin{tabular}{|c|c|c|c|}
\hline & Morphometric parameters & Formula/Definition & References \\
\hline 1 & Stream order $(u)$ & Hierarchical rank & [35] \\
\hline 2 & No. of streams $\left(N_{u}\right)$ & $N=N_{1}+N_{2}+\cdots+N_{u}$ & [33] \\
\hline 3 & Stream length $\left(L_{u}\right)$ & $L_{u}=L_{1}+L_{2}+\cdots+L_{u}(\mathrm{Km})$ & [36] \\
\hline 4 & Bifurcation ratio $\left(R_{b}\right)$ & $R_{b}=N_{u} / N_{u}+1$ & [35] \\
\hline 5 & Basin length $\left(L_{b}\right) \mathrm{Km}$ & Length of basin $(\mathrm{Km})$ & [33] \\
\hline 6 & Basin area $(A) \mathrm{Km}^{2}$ & Plan area of the watershed $(\mathrm{Km})$ & [33] \\
\hline 7 & Basin perimeter $(P) \mathrm{Km}$ & Perimeter of the watershed $(\mathrm{Km})$ & [33] \\
\hline 8 & Elongation ratio $\left(R_{e}\right)$ & $1.128 \sqrt{A} / L_{b}$ & [39] \\
\hline 9 & Shape factor $\left(S_{f}\right)$ & $S_{f}=L_{b}^{2} / A$ & [33] \\
\hline 10 & Circularity ratio $\left(R_{c}\right)$ & $R_{c}=4 \times 3.14 \times \mathrm{A} / P^{2}$ & [36] [38] \\
\hline 11 & Compactness coefficient $\left(C_{c}\right)$ & $C_{c}=0.2812 \times P / A^{0.5}$ & [33] \\
\hline 12 & Stream frequency $\left(F_{s}\right)$ & $F_{s}=N_{u} / A$ & [33] \\
\hline 13 & Drainage density $\left(D_{d}\right) \mathrm{Km} / \mathrm{Km}^{2}$ & $D_{d}=L_{u} / A$ & [33] \\
\hline 14 & Length of overland flow $\left(L_{o}\right)$ & $L_{o}=1 / 2 D_{d}$ & [33] \\
\hline 15 & Basin relief $\left(B_{h}\right)$ or total relief $(H)(\mathrm{m})$ & $\begin{array}{c}B_{h}=h-h_{1} \text {, where, } h=\text { maximum height }(\mathrm{m}) \\
h_{1}=\text { minimum height }(\mathrm{m})\end{array}$ & [83] \\
\hline 16 & Relief ratio $\left(R_{r}\right)$ & $R_{r}=H / L_{b}$, where $H=$ total relief, $L_{b}=$ basin length & [39] \\
\hline 17 & Ruggedness number $\left(R_{n}\right)$ & $R_{n}=D_{d} \times\left(B_{h} / 1000\right)$ & {$[36]$} \\
\hline 18 & Hypsometric integral $\left(H_{i}\right)$ & $\begin{array}{l}H_{i}=\left(H^{-}-H\right) /(H-h) \text {, where } H^{-}=\text {the weighted mean } \\
\text { elevation, } H=\text { maximum elevation, } h=\text { minimum elevation }\end{array}$ & [34] \\
\hline 19 & Basin slope (degree) $(D)$ & $B_{h} / L_{b} \times 60$ & - \\
\hline 20 & Geometry number $\left(G_{n}\right)$ & $G_{n}=B_{h} \times D_{d} / D$, where $D=$ slope degree & [82] \\
\hline
\end{tabular}




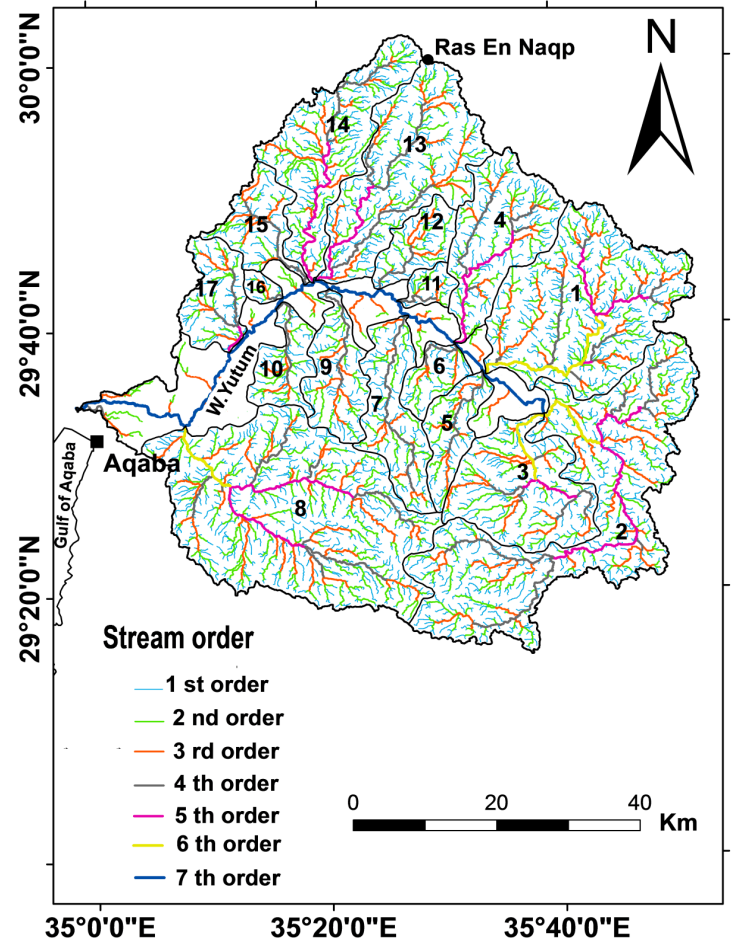

Figure 6. Stream order of the 17 sub-basins.

aspect, six parameters depict basin geometry aspect, three represent drainage texture aspect, and five describe the relief characteristics aspect. Group I accommodates ten morphometric parameters which have a direct proportion to the degree of risk. Consequently, the higher the parameter value, the higher the risk degree. This group comprises the following parameters:

sub-basin area $(A)$, circularity ratio $\left(R_{c}\right)$, sub-basin relief $\left(B_{h}\right)$, relief ratio $\left(R_{f}\right)$, drainage density $\left(D_{d}\right)$, stream frequency $\left(F_{s}\right)$, stream order $(U)$, total stream number $\left(N_{u}\right)$, total stream length $\left(L_{u}\right)$, and sub-basin slope (degrees) $\left(S_{w}\right)$.

Group II comprises seven parameters which are inversely proportional to the risk. Subsequently, the higher the parameter value, the lower the degree of risk. This group consists of the following parameters: elongation ratio $\left(R_{e}\right)$, shape factor $\left(B_{s}\right)$, compactness coefficient $\left(C_{c}\right)$, ruggedness number $\left(R_{n}\right)$, hypsometric integral $\left(H_{i}\right)$, geometry number $\left(G_{n}\right)$, and length of overland flow $\left(L_{o}\right)$. The bifurcation ratio $\left(R_{b}\right)$ has also been calculated in order to be employed in El-Shamy's approach (or the second method), along with drainage density $\left(D_{d}\right)$ and stream frequency parameters $\left(F_{s}\right)$. Based on the computed values of the seventeen morphometric parameters, it is possible to calculate the flash flood risk according to the following steps:

With reference to the relationship between the values of the morphometric parameters and the risk of flash floods, the evaluation of each parameter has been carried out using a simple statistical approach elaborated and employed by Pradhan [84] and Youssef et al. [51]. Each morphometric parameter is classified into five rank categories. Rank 1 refers to low risk, and rank 5 denotes high risk. The equation applied is (Max-Min)/5. Then the values for each parameter are categorized into five intervals. For group I parameters, the higher the parameter value, the higher the degree of risk, thus the higher the rank. By contrast, for the group II of parameters, the higher the parameter value, the lower the degree of risk, hence, the lower the rank. Then the morphometric parameter values for each sub-basin were summed and normalized in order to obtain a morphometric number for each sub-basin. Based upon these summated numbers, the sub-basins were classified in terms of their risk of occurrence of flash floods.

\subsection{El-Shamy's Approach}

The second approach for assessing susceptibility of sub-basins to flash flooding risk is that developed by El-Shamy [11]. He designates a simple morphometric method to estimate the flash flood risk levels and the de- 
gree of hazardousness for each sub-basin. Two different approaches were elaborated to determine the hazardous sub-watersheds. The first is based on the relationship between bifurcation ration $\left(R_{b}\right)$ and drainage density $\left(D_{d}\right)$, whereas the second approach utilized the relationship between bifurcation ratio $\left(R_{b}\right)$ and stream frequency $\left(F_{s}\right)$. Drainage density $\left(D_{d}\right)$ refers to topographic dissection, runoff potential, infiltration capacity of surface materials, climate, and land cover of the watershed. In this regard, low values of $D_{d}$ indicate optimal conditions for infiltration, thus decreasing runoff potential, while, high stream frequency $\left(F_{s}\right)$ represents impermeable sub-surface materials, poor vegetation cover, high relief, and low infiltration capacity, hence increasing runoff potential [11] [12]. Applying this relationship separately to each sub-basin will provide reasonable information on estimation of flooding risk and recharge potential. In order to assess such relations, three morphometric parameters $\left(R_{b}, D_{d}\right.$, and $F_{s}$ ) must be calculated for each sub-basin [53].

The resultant illustrations for $D_{d} R_{b}$ and $F_{s} R_{b}$ have to be plotted graphically, where each illustration contains two curves, dividing the area into three fields. These fields are described as follows:

- Field A refers to low possibility for floods, and high recharge potential.

- Field B represents sub-basins with intermediate possibility for floods and moderate potential for groundwater recharge.

- Field C indicates high possibility for floods and low recharge property. If a sub-watershed has two different fields, then the appropriate classification plot has been selected.

However, an integration of the results was achieved based on the morphometric ranking method with ElShamy's model. Such a procedure was executed through superimposition of flood risk map produced according to the morphometric ranking method, with the flood risk map generated through El-Shamy's approach. This task would make it possible to identify: (i) the common sub-watersheds falling under each category of flooding risk, (ii) determine the most risky sub-watersheds in terms of flash flooding, and (iii) recognize the most vulnerable sites/sub-basins against flooding, and the section of Amman-Aqaba highway (across W. Yutum)which may be affected by flood damage in the future.

\section{Results and Discussion}

A methodology for flash floods assessment has been employed to understand the nature and extent of flooding risk within W. Yutum watershed. The potential hazard was analyzed, and areas vulnerable to flooding, and expected to cause heavy damage to the residents and their livelihood were delineated. Since the 1950s, W. Yutum and Aqaba City were exposed to flash floods of different magnitudes, as a result of climatic conditions, human intervention and engineering activities, and recurrent heavy rainfall storms. In order to assess the hazardous effect of flash floods on seventeen sub-basins related to W. Yutum, hydro-morphometric parameters were utilized in the analysis. The degree of flooding risk characterizing each sub-basin was established using two different methods: (a) El-Shamy's approach for flooding hazard assessment based on three morphometric parameters;and (b) the morphometric ranking method elaborated in [12] [51] [82] [83]. The second method is considered a semi-quantitative measure determined on seventeen morphometric parameters.

\subsection{Flash Floods Risk Assessment: El-Shamy's Approach}

In line with this approach, the relationship between bifurcation ratio $\left(R_{b}\right)$ and drainage density $\left(D_{d}\right)$, and then the relationship between $\mathrm{R}_{\mathrm{b}}$ and stream frequency $\left(F_{s}\right)$ have been utilized. The bifurcation ratios for the seventeen sub-basins range between 3.13 and 7.16, whereas, the mean bifurcation ratio for the entire W. Yutum is 4.6, which suggests a remarkable influence of structural control on sub-basins nos. 4, 5, 7, 9, 10,12, 13, 14, 15, and 17. Little influence was observed on sub-basins nos. 3, 11 and 16 (Table 2). Furthermor, low values were achieved for the inselbergs - sand sheet areas. In general, these range between 1.29 and 2.66. Such figures indicate high infiltration, thereby decreasing runoff potential. By contrast, relatively high stream frequency values characterized the granite watersheds, which denotes impermeable sub-surface materials, sparse vegetation, high-rugged terrain, and low infiltration capacity.

Sub-basins vulnerable and exposed to flash flooding were demarcated and assessed in order to determine sub-basins of low, intermediate and high susceptibility to flooding based on the relationship of the two morphometric parameters ( $R_{b}$ vs. $D_{d}$ and $R_{b}$ vs. $F_{s}$ ); the final flood hazard map was then generated with the help of Arc GIS tool. Based on the relationship between $R_{b}$ and $D_{d}$, sub-basins nos. 1 (the eastern part of Ras En Naqb 
Table 2. Morphometric characteristics of W. Yutum sub-basins.

\begin{tabular}{|c|c|c|c|c|c|c|c|c|c|c|c|c|c|c|c|c|c|}
\hline \multirow{2}{*}{$\begin{array}{c}\text { Morpho. } \\
\text { Parameters }\end{array}$} & \multicolumn{17}{|c|}{ Sub basins } \\
\hline & 1 & 2 & 3 & 4 & 5 & 6 & 7 & 8 & 9 & 10 & 11 & 12 & 13 & 14 & 15 & 16 & 17 \\
\hline$A$ & 488.69 & 672.96 & 272.87 & 239.05 & 92.51 & 33.98 & 164.31 & 770.95 & 127.52 & 86.03 & 32.80 & 83.70 & 367.58 & 287.75 & 104.87 & 718.11 & 110.33 \\
\hline$P$ & 109.76 & 229.13 & 80.90 & 79.94 & 49.90 & 59.56 & 76.71 & 144.61 & 62.51 & 52.12 & 26.73 & 42.42 & 106.80 & 111.21 & 63.19 & 16.92 & 52.30 \\
\hline$L_{b}$ & 32.83 & 58.07 & 22.47 & 28.90 & 21.08 & 11.47 & 29.41 & 43.40 & 21.86 & 16.68 & 8.65 & 15.54 & 32.92 & 37.58 & 16.67 & 6.69 & 17.31 \\
\hline$B_{h}$ & 662 & 984 & 713 & 773 & 863 & 839 & 957 & 1399 & 974 & 823 & 495 & 667 & 927 & 896 & 675 & 608 & 899 \\
\hline$R_{r}$ & 0.020 & 0.016 & 0.031 & 0.026 & 0.040 & 0.073 & 0.032 & 0.032 & 0.044 & 0.049 & 0.056 & 0.042 & 0.028 & 0.023 & 0.040 & 0.090 & 0.051 \\
\hline$D$ & 1.209 & 1.016 & 1.903 & 1.604 & 2.455 & 4.388 & 1.952 & 1.934 & 2.673 & 2.960 & 3.433 & 2.575 & 1.689 & 1.430 & 2.429 & 5.452 & 3.116 \\
\hline$R_{n}$ & 0.99 & 1.42 & 1.00 & 1.09 & 1.34 & 2.23 & 1.42 & 2.09 & 1.46 & 1.30 & 0.77 & 1.04 & 1.37 & 1.42 & 0.98 & 0.78 & 1.28 \\
\hline$H_{i}$ & 0.739 & 0.712 & 0.756 & 0.760 & 0.777 & 0.673 & 0.725 & 0.792 & 0.703 & 0.762 & 0.506 & 0.626 & 0.736 & 0.682 & 0.806 & 0.772 & 0.813 \\
\hline$G_{n}$ & 0.826 & 1.404 & 0.528 & 0.684 & 0.548 & 0.508 & 0.730 & 1.085 & 0.546 & 0.439 & 0.226 & 0.404 & 0.812 & 0.996 & 0.405 & 0.143 & 0.412 \\
\hline$U$ & 6 & 6 & 6 & 5 & 4 & 4 & 4 & 6 & 4 & 4 & 4 & 4 & 5 & 5 & 4 & 4 & 4 \\
\hline$N_{u}$ & 637 & 806 & 332 & 313 & 136 & 71 & 204 & 923 & 155 & 114 & 47 & 111 & 444 & 367 & 133 & 25 & 142 \\
\hline$L_{u}$ & 739.23 & 978.34 & 386.25 & 340.79 & 144.95 & 90.58 & 245.18 & 1158.78 & 191.39 & 136.44 & 451.54 & 130.68 & 8545.09 & 459.52 & 153.95 & 23.41 & 158.53 \\
\hline$R_{b}$ & 3.51 & 3.88 & 3.13 & 3.94 & 4.87 & 3.82 & 7.60 & 3.78 & 4.99 & 4.49 & 3.34 & 4.52 & 4.49 & 4.20 & 4.85 & 2.55 & 4.82 \\
\hline $\begin{array}{c}D_{d} \\
\left(\mathrm{Km} / \mathrm{Km}^{2}\right)\end{array}$ & 1.51 & 1.45 & 1.41 & 1.42 & 1.56 & 2.66 & 1.49 & 1.50 & 1.50 & 1.58 & 1.57 & 1.56 & 1.48 & 1.59 & 1.46 & 1.29 & 1.43 \\
\hline $\begin{array}{c}F_{s} \\
\left(\mathrm{Nu} / \mathrm{Km}^{2}\right)\end{array}$ & 1.30 & 1.19 & 1.21 & 1.30 & 1.47 & 2.08 & 1.24 & 1.19 & 1.21 & 1.32 & 1.43 & 1.32 & 1.20 & 1.27 & 1.26 & 1.38 & 1.28 \\
\hline$L_{o}$ & 0.75 & 0.72 & 0.70 & 0.71 & 0.78 & 1.33 & 0.74 & 0.75 & 0.75 & 0.79 & 0.78 & 0.78 & 0.74 & 0.79 & 0.73 & 0.64 & 0.71 \\
\hline$R_{e}$ & 0.75 & 0.50 & 0.82 & 0.60 & 0.51 & 0.57 & 0.48 & 0.72 & 0.58 & 0.62 & 0.74 & 0.66 & 0.65 & 0.50 & 0.69 & 0.71 & 0.68 \\
\hline$R_{c}$ & 0.50 & 0.16 & 0.52 & 0.46 & 0.46 & 0.12 & 0.35 & 0.46 & 0.40 & 0.39 & 0.57 & 0.58 & 0.40 & 0.29 & 0.32 & 0.79 & 0.50 \\
\hline$S_{f}$ & 0.453 & 0.199 & 0.540 & 0.286 & 0.208 & 0.258 & 0.189 & 0.409 & 0.266 & 0.309 & 0.438 & 0.346 & 0.339 & 0.203 & 0.377 & 0.404 & 0.368 \\
\hline$C_{c}$ & 1.401 & 2.492 & 1.381 & 1.458 & 1.463 & 2.883 & 1.688 & 1.469 & 1.561 & 1.585 & 1.317 & 1.308 & 1.571 & 1.849 & 1.741 & 1.122 & 1.405 \\
\hline
\end{tabular}

$(A)$ area, $(P)$ perimeter, $\left(L_{b}\right)$ length, $\left(B_{h}\right)$ relief, $\left(R_{r}\right)$ relief ratio, $(D)$ slope (degrees), $\left(R_{n}\right)$ ruggedness number, $\left(H_{i}\right)$ hypsometric integral, $\left(G_{n}\right)$ geometry number, $(u)$ stream order, $\left(N_{u}\right)$ total stream number, $\left(L_{u}\right)$ total stream length, $\left(R_{b}\right)$ bifurcation ratio, $\left(D_{d}\right)$ drainage density, $\left(F_{s}\right)$ stream frequency, $\left(L_{o}\right)$ length of overland flow, $\left(R_{e}\right)$ elongation ratio, $\left(R_{c}\right)$ circularity ratio, $\left(S_{f}\right)$ shape factor, $\left(C_{c}\right)$ compactness coefficient.

escarpment), 3 (Q'a Disa-El Ghal), 8 (Yutum El-Umran), 11 and 16 (Figure 7 and Figure 8) are characterized as having high susceptibility to flooding. Sub-basins nos. 2, 4 (middle part of Ras En Naqb escarpment), 6, 10 (W. Marsad and W. Rumman), 12, 13, and 14 (northwestern part of the granite horst) represent the category of intermediate flooding susceptibility. By contrast, sub-basins nos. 5, 7, 9 (inselberg landscape), 15 and 17 are of low susceptibility to flooding. Similarly, and based on the relationship between $R_{b}$ and $F_{s}$ (Figure 9), sub-basins nos. 1, 3, 8, 11 and 16 are considered of high susceptibility to flooding, while, sub-basins 2, 4, 6 and 14 are of intermediate susceptibility to flooding. Furthermore, sub-basins 5, 7, 9, 10, 12, 13, 15 and 17 are ranked as having low susceptibility to flooding.

Field observations reveal that the section of the old Amman-Aqaba highway was routed initially along W. Yutum bed at the lower catchment, and has been damaged several times due to flash floods. Following 1973, this section of the highway was re-located five meters above a fluvial terrace to protect the highway against flooding. However, a hydrological investigation [26] reported that a flood of 50-year return period (resembling the Ma'an flood of 1966) or greater is likely to damage this section of the highway, assuming that surface water will rise 0.3 - $0.5 \mathrm{~m}$ above the present road surface, with relative high velocities. The most hazardous sub-basin found is sub-watershed no. 8 (Yutum El-Umran), located completely on granite, and representing an area of $770.95 \mathrm{~km}^{2}$ (17.5\% of the total area) of the W. Yutum watershed. At the lower W. Yutum, a water gap has been 


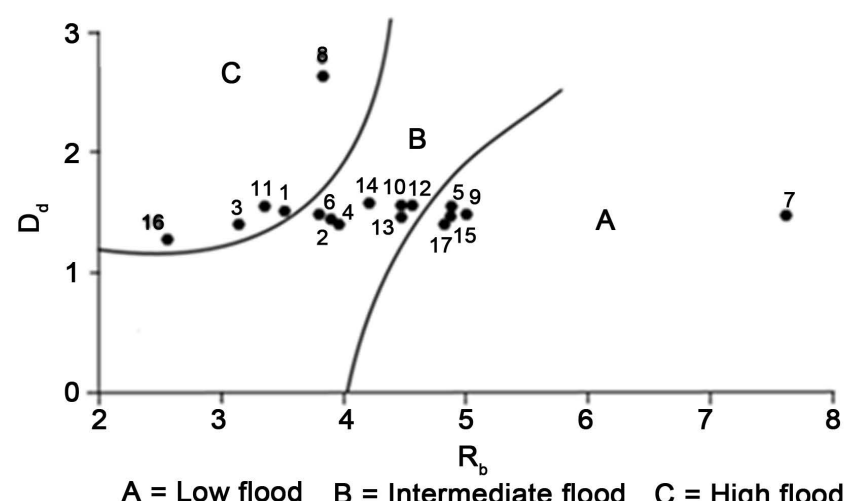

(a)

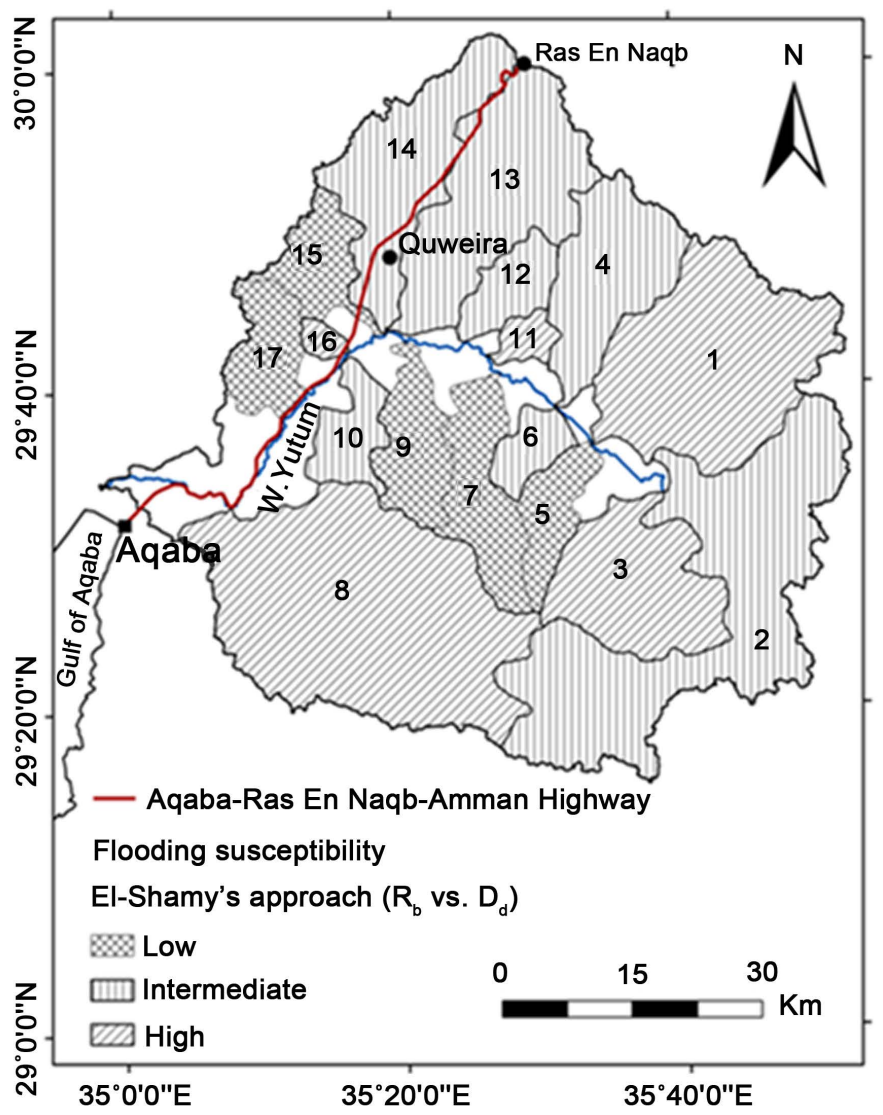

(b)

Figure 7. (a) \& (b) Flooding susceptibility: El-Shamy’s approach $\left(R_{b}\right.$ vs. $\left.D_{d}\right)$.

formed and has diverted the main W. Yutum watershed towards the Gulf of Aqaba. The water gap starts where the present main wadi course changes its southerly direction by $90^{\circ}$ to follow a western course through a prominent gorge cut $400 \mathrm{~m}$ in a granite saddle. For the last few kilometers above the recent fan apex, the wadi floor narrows to less than $100 \mathrm{~m}$ between the bases of the granite rock walls on both sides. This water gap has been established by a westerly flowing stream which continued its headward erosion until it captured the interior basin just a few kilometers below the entrance of the main tributary of Yutum El-Umran. During the erosional phase following wadi diversion, the pirate stream extended its course rapidly in the easily eroded alluvium to form the main channel of the present Wadi Yutum across the axis of the watershed. Successive phases of incision may be attributed either to rift tectonics and subsidence of the Rift valley floor, or may be correlated with sea level fluctuations as the new wadi reached the Gulf [66] [85]. Moreover, it is also obvious, that the most ha- 


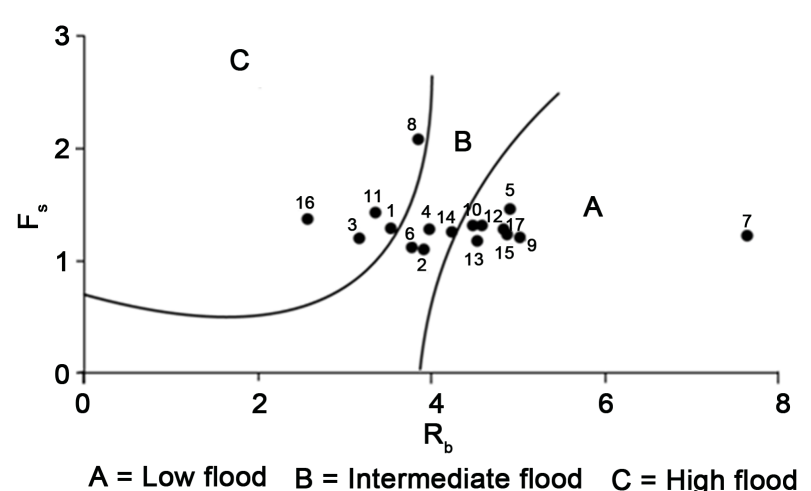

(a)

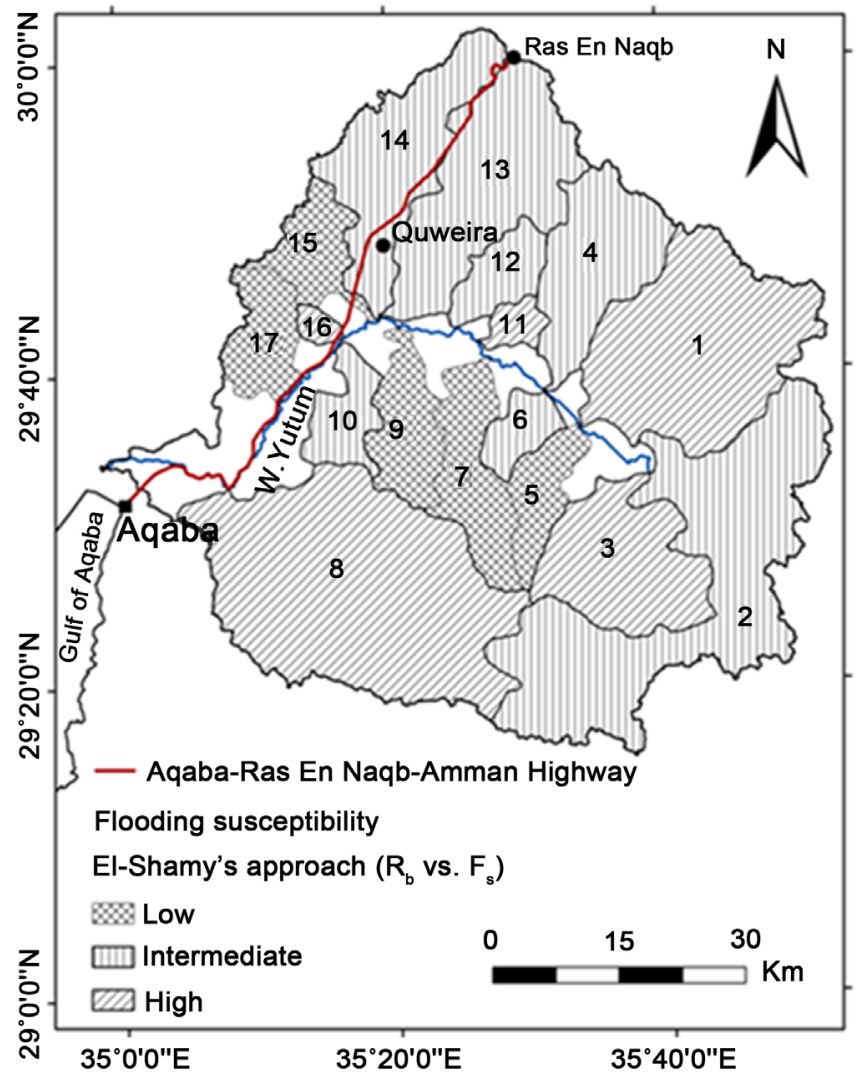

(b)

Figure 8. (a) \& (b) Flooding susceptibility: El-Shamy’s approach $\left(R_{b}\right.$ vs. $\left.F_{s}\right)$.

zardous basin located on sedimentary carbonate rocks is sub-basin no. 1 (area: $488.69 \mathrm{~km}^{2}$, $11 \%$ of the total area). By contrast, sub-basins nos. 4 and 13 are of intermediate susceptibility to flash flooding. However, the relative abundance of rainfall on the Ras En Naqb area and the presence of heavily jointed, fissured weak lithology, facilitate landsliding activity along the section of the highway extending between Ras En Naqb town and north of Quweira. Thereby, repetitive landslides have disrupted the highway occasionally.

It can be concluded that similar and consistent results of flood hazard susceptibility can be achieved through El-Shamy's approach for sub-basins categorized based on the relationship between $R_{b}$ vs. $D_{d}$, and the relationship between $R_{b}$ vs. $F_{s}$ (Figure 7 and Figure 8). For example, sub-basins nos. 1, 3, 8, 11, and 16 are categorized in both morphometric relationships under the class of high flooding susceptibility. Moreover, sub-basins nos. 2 , 4, 6, and 14 are ranked under the intermediate flooding susceptibility and sub-basins 5, 7, 9, 15, and 17 are classified under low flooding susceptibility. 


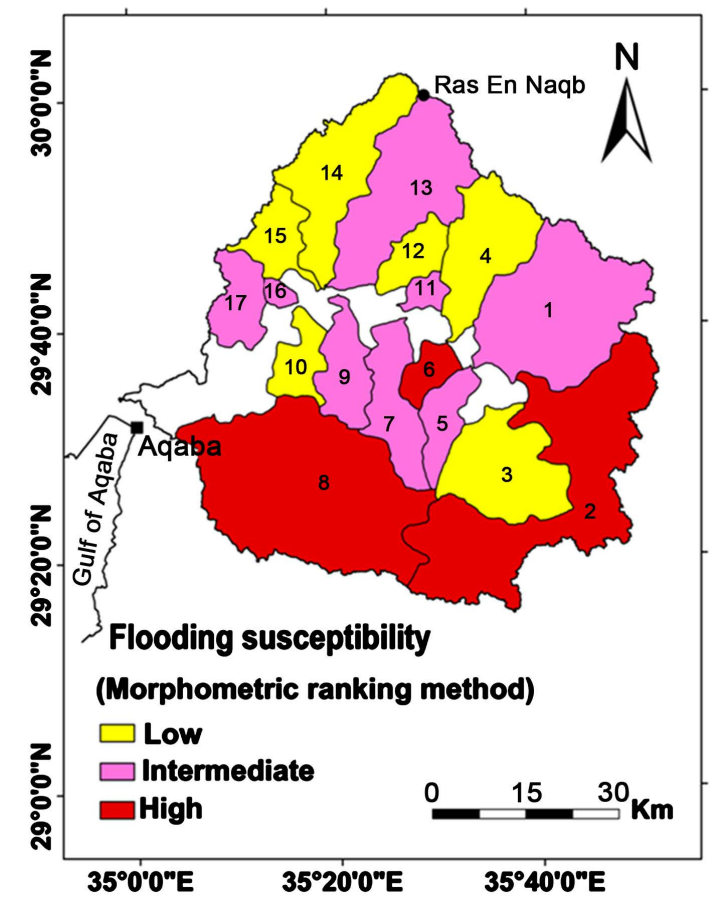

Figure 9. Flooding susceptibility: morphometric ranking method.

\subsection{Flash Floods Risk Assessment: Morphometric Ranking Method}

The morphometric ranking method for determining the flash flood hazard and the degree of risk for the seventeen sub-basins, was applied to execute the required morphometric analysis. Table 3 illustrates the results of this method as expressed by ranking score for different morphometric parameters along with the total score values for each sub-basin. To generate the flood risk map using GIS, the total score values for the seventeen sub-basins were grouped into three categories of flooding susceptibility.
1) Low flooding susceptibility
$(30-40)$
2) Intermediate flooding susceptibility
3) High flooding susceptibility

With respect to the seventeen sub-basins of W. Yutum watershed, sub-basins nos. 3, 4, 10, 12, 14, and 15 (35.3\% of the total) have the lowest overall values, therefore representing the low flooding susceptibility rank (Table 3 and Figure 9). Whereas, sub-basins nos. 1, 5, 7, 9, 11, 13, 16 and 17 (47\% of the total) have intermediate score values, thus characterized by moderate flooding susceptibility. By contrast, sub-basins nos. 2, 6, and 8 (17.7\% of the total) have the highest overall score values, and thus represent the most dangerous sub-basins with high flooding susceptibility. In this regard two-thirds of W. Yutum sub-basins are expected to suffer moderate and high susceptibility to flooding. The results also indicated that the main hazardous and threatening sub-basins are located on the basement complex (granite), i.e. the lower part of W. Yutum and its major tributary Yutum El-Umran, and sub-basins descending from Ras en Naqb escarpment. Here, flash floods are mostly contributed by these sub-basins. Other sub-basins which terminated to the playas of the inselberg landscape are often of low susceptibility to flooding. Consequently, the Amman-Aqaba highway and the alluvial fan of W. Yutum which at present accommodate a considerable residential area, the Aqaba International Estate, the King Hussein International Airport, and the Northern Light Industrial and Logistic Area are seriously threatened by flooding. Thus, the protection of the city from repetitive flooding is essential to maintain future urban and economic development.

An integration of the results achieved based on the morphometric ranking method and El-Shamy's approach was conducted through superimposition of the layers/maps produced. Such a procedure makes it possible to recognize the common sub-basins falling under each category of flooding susceptibility. The correlation shows that sub-basin no. 8 is the common sub-basin and ranked under high flooding susceptibility (Table 4, Figure 10 and Figure 11). Similarly, sub-basin no.13 is a common sub-basin and classified under moderate flooding sus- 


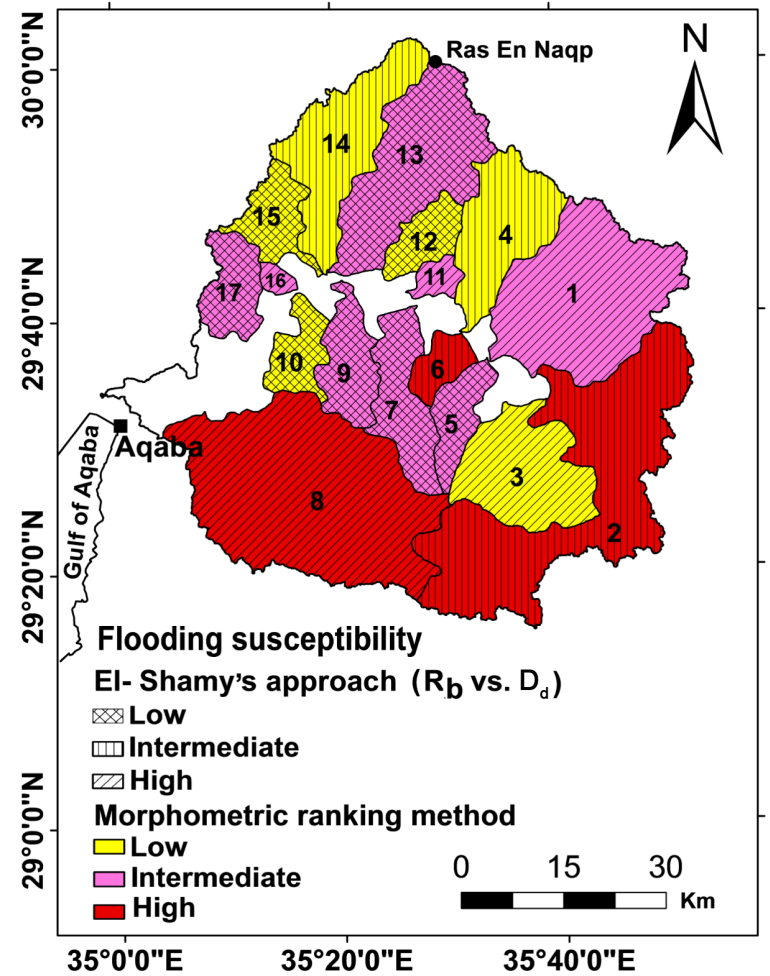

Figure 10. Flooding susceptibility: Shamy's approach $\left(R_{b}\right.$ vs. $\left.D_{d}\right) \&$ morphometric ranking method.

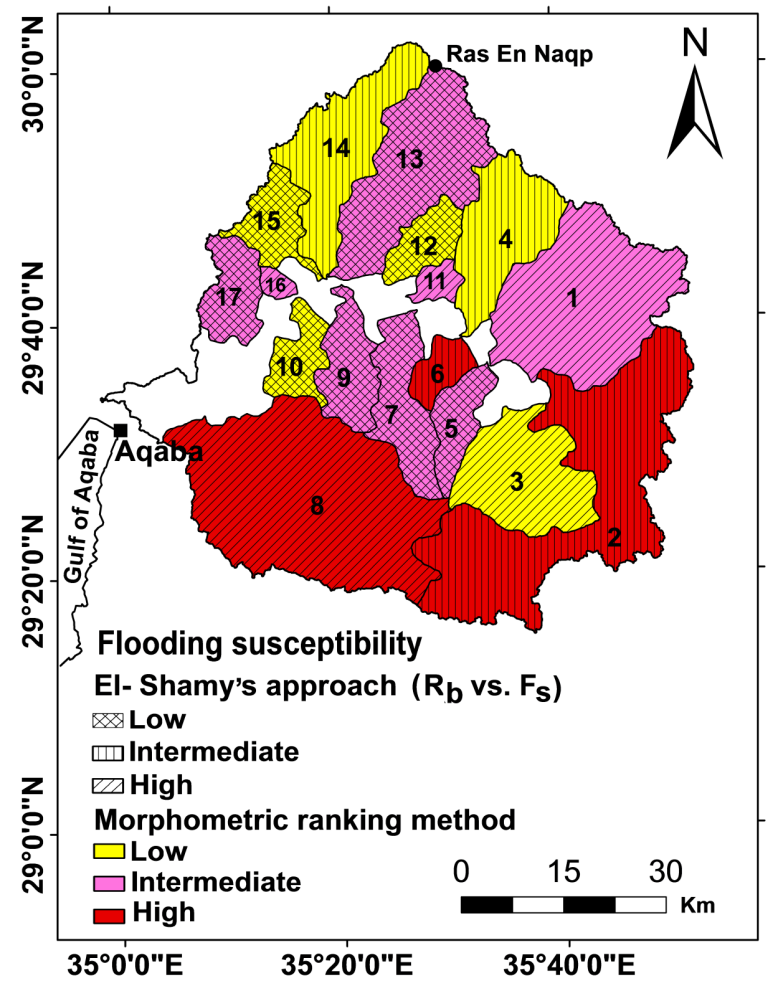

Figure 11. Flooding susceptibility: Shamy’s approach $\left(R_{b}\right.$ vs. $\left.F_{s}\right) \&$ morphometric ranking method. 
Table 3. Ranks score for different morphometric parameters and the total score value.

\begin{tabular}{|c|c|c|c|c|c|c|c|c|c|c|c|c|c|c|c|c|c|}
\hline \multirow{2}{*}{$\begin{array}{l}\text { Morphometric } \\
\text { Parameters }\end{array}$} & \multicolumn{17}{|c|}{ Sub basins } \\
\hline & 1 & 2 & 3 & 4 & 5 & 6 & 7 & 8 & 9 & 10 & 11 & 12 & 13 & 14 & 15 & 16 & 17 \\
\hline A & 4 & 5 & 2 & 2 & 1 & 1 & 1 & 5 & 1 & 1 & 1 & 1 & 3 & 2 & 1 & 1 & 1 \\
\hline$B_{h}$ & 1 & 3 & 2 & 2 & 3 & 2 & 3 & 5 & 3 & 2 & 1 & 1 & 3 & 3 & 1 & 1 & 3 \\
\hline$R_{r}$ & 1 & 1 & 2 & 1 & 2 & 4 & 2 & 2 & 2 & 3 & 3 & 2 & 1 & 1 & 2 & 5 & 3 \\
\hline$S_{w}$ & 1 & 1 & 1 & 1 & 2 & 4 & 2 & 2 & 2 & 3 & 3 & 2 & 1 & 1 & 2 & 5 & 3 \\
\hline$R_{c}$ & 3 & 1 & 3 & 3 & 3 & 1 & 2 & 3 & 3 & 3 & 4 & 4 & 3 & 1 & 2 & 5 & 3 \\
\hline$D_{d}\left(\mathrm{Km} / \mathrm{Km}^{2}\right)$ & 1 & 1 & 1 & 1 & 1 & 5 & 1 & 1 & 1 & 2 & 2 & 1 & 1 & 2 & 1 & 1 & 1 \\
\hline$F_{s}\left(\mathrm{Nu} / \mathrm{Km}^{2}\right)$ & 1 & 1 & 1 & 1 & 2 & 5 & 1 & 1 & 1 & 1 & 2 & 1 & 1 & 1 & 1 & 2 & 1 \\
\hline$U$ & 5 & 5 & 5 & 1 & 3 & 3 & 3 & 5 & 1 & 1 & 1 & 1 & 3 & 3 & 1 & 1 & 1 \\
\hline$N_{u}$ & 4 & 5 & 2 & 2 & 1 & 1 & 1 & 5 & 1 & 1 & 1 & 1 & 3 & 2 & 1 & 1 & 1 \\
\hline$L_{u}$ & 4 & 5 & 2 & 2 & 1 & 1 & 1 & 5 & 1 & 1 & 1 & 1 & 3 & 2 & 1 & 1 & 1 \\
\hline$R_{e}$ & 2 & 5 & 1 & 4 & 5 & 4 & 5 & 2 & 4 & 3 & 2 & 3 & 3 & 5 & 2 & 2 & 3 \\
\hline$S_{f}$ & 2 & 5 & 1 & 4 & 5 & 5 & 5 & 2 & 4 & 4 & 2 & 3 & 3 & 1 & 3 & 2 & 3 \\
\hline$C_{c}$ & 5 & 3 & 5 & 5 & 5 & 1 & 4 & 5 & 4 & 4 & 5 & 5 & 4 & 3 & 4 & 5 & 5 \\
\hline$R_{n}$ & 1 & 3 & 1 & 2 & 2 & 5 & 3 & 5 & 3 & 2 & 1 & 1 & 2 & 3 & 1 & 1 & 2 \\
\hline$H_{i}$ & 2 & 2 & 1 & 1 & 1 & 3 & 2 & 1 & 2 & 1 & 5 & 4 & 2 & 3 & 1 & 1 & 1 \\
\hline$G_{n}$ & 3 & 1 & 4 & 3 & 4 & 4 & 3 & 2 & 4 & 4 & 5 & 4 & 3 & 2 & 4 & 5 & 4 \\
\hline$L_{o}$ & 5 & 5 & 5 & 5 & 4 & 1 & 5 & 5 & 5 & 4 & 4 & 4 & 5 & 4 & 5 & 5 & 5 \\
\hline Total & 45 & 52 & 39 & 40 & 45 & 50 & 44 & 56 & 42 & 40 & 43 & 39 & 44 & 39 & 33 & 44 & 41 \\
\hline
\end{tabular}

Table 4. Classification of sub-basins flooding susceptibility based on the two methods employed in flash floods assessment.

\begin{tabular}{|c|c|c|c|}
\hline $\begin{array}{c}\text { Flash floods } \\
\text { assessment method }\end{array}$ & $\begin{array}{l}\text { Sub-basins of high } \\
\text { flooding susceptibility }\end{array}$ & $\begin{array}{l}\text { Sub-basins of intermediate } \\
\text { flooding susceptibility }\end{array}$ & $\begin{array}{l}\text { Sub-basins of low } \\
\text { flooding susceptibility }\end{array}$ \\
\hline $\begin{array}{l}\text { Morphometric } \\
\text { ranking method }\end{array}$ & $8^{*}$ & $\begin{array}{lrlll}1 & 5 & 7 & 9 & 11 \\
13^{*} & 16 & 17\end{array}$ & 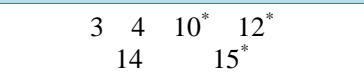 \\
\hline $\begin{array}{c}\text { El-Shamy's } \\
\text { approach }\left(R_{b} \text { vs. } D_{d}\right)\end{array}$ & $1+2+8^{*} 11+16+$ & $2+4+6+101213^{*} 14+$ & $5+7+9+15^{*} 17+$ \\
\hline$\left(R_{b}\right.$ Vs. $\left.F_{s}\right)$ & $1+3+8^{*} 11+16+$ & $2+4+6+14+$ & $5+7+9+10^{*} 12^{*} 1315^{*} 17+$ \\
\hline
\end{tabular}

${ }^{*}$ Correlation between sub-basins under the two methods of floods risk assessment. ${ }^{+}$Correlation between sub-basins under the two morphometric relationships proposed by El-Shamy for flood risk assessment.

ceptibility based on both the morphometric ranking method and El-Shamy's method $\left(R_{b}\right.$ vs. $\left.D_{d}\right)$. Moreover, three sub-basins, nos. 10, 12 and 15, are also common, and ranked under the category of low flooding susceptibility. Sub-basin no. 6 is categorized under high flooding susceptibility based on the morphometric ranking method, and is classified under intermediate flooding susceptibility based on El-Shamy's approach. Equally, two sub-basins nos.9 and 17 are ranked under intermediate flooding susceptibility based on the morphometric ranking method, and of low flooding susceptibility based on El-Shamy's approach. In parallel, sub-basins nos. 10 and 12 are ranked under low susceptibility to flooding based on the morphometric ranking method, and ElShamy's approach $\left(R_{b}\right.$ vs. $\left.F_{s}\right)$, and of intermediate flooding category based on El-Shamy's approach $\left(R_{b}\right.$ vs. $\left.D_{d}\right)$. It can be demonstrated that $47 \%$ ( 8 sub-basins) of the total number of sub-basins can be categorized under high flooding susceptibility based on the morphometric ranking method, and El-Shamy's approach. Thus they are considered the highly hazardous sub-basins within W. Yutum watershed. GIS tool and field observations enable assessment of flooding risk, and demarcation of flood-prone sub-basins as displayed on the drainage basin hazard map. 


\section{Conclusions}

In the present investigation, GIS based hydro-morphometric analysis, field and satellite data were employed to estimate flash flood risk, and to compile a spatial potential flood hazard map which illustrated flash flood prone-areas across W. Yutum watershed. The generated maps/information were meant to help planners and decision makers understand the spatial distribution of flood hazard conditions, in order to formulate flood protection measures to minimize the negative impacts of repetitive flooding on the residents and infrastructure of Aqaba city. Floods risk analysis was performed using two morphometric analysis methods. With the aid of GIS, it was possible to delineate the sub-basins of W. Yutum which might be affected by floods of low, moderated and high susceptibility. Results of flash flood risk estimation based on the relationship between $R_{b}$ and $D_{d}$ (El-Shamy's approach) showed that sub-basins nos. 1, 3, 8, 11 and 16 were characterized as being of high susceptibility to flooding, whereas, sub-basins nos. 2, 4, 6, 10, 12, 13 and 14 represented the category of moderate flooding susceptibility. By contrast, sub-basins nos. 5, 7, 9, 15 and 17 are classified under the category of low flooding susceptibility. Similarly, and based on the relationship between $R_{b}$ and $F_{s}$, sub-basins nos. 1, 3, 8, 11 and 16 are categorized as of high susceptibility to flooding, while, sub-basins nos. 2, 4, 6 and 14 are of intermediate susceptibility to flooding. Furthermore, sub-basins 5, 7, 9, 10, 12, 13, 15 and 17 are considered to be of low susceptibility to flooding.

Based on the morphometric ranking method, sub-basins nos. 3, 4, 10, 12, 14, and 15 (35\% of the total) have the lowest overall score values, and thus represent the low flooding susceptibility rank. Sub-basins nos. 1, 5, 7, $9,11,13,16$, and 17 (47\% of the total) have intermediate score values, and thus are characterized by moderate flooding susceptibility. By contrast, sub-basins nos. 2, 6, and 8 (17.7\% of the total) have the highest overall score values and consequently, represent the most dangerous sub-basins with high flooding susceptibility. In this regard, two-thirds of W. Yutum sub-basins are expected to suffer moderate and high flooding susceptibility.

However, the superimposition of the thematic maps produced based on the morphometric ranking method, and El-Shamy's approach, showed that sub-basin no. 8 is the common sub-basin and ranked under high flooding susceptibility. Similarly, sub-basin no. 13 is a common sub-basin and classified under moderate flooding susceptibility based on both the morphometric ranking method and El-Shamy's approach $\left(R_{b}\right.$ vs. $\left.D_{d}\right)$. Moreover, three sub-basins nos.10,12, and 15 are also common, and ranked under the category of low flooding susceptibility. Sub-basin no.6 is categorized under high flooding liability based on the morphometric ranking method, and is classified under moderate flooding potentiality based on El-Shamy's approach. In parallel, two sub-basins nos. 9 and 17 are ranked under moderate flooding susceptibility based on morphometric ranking method, and of low flooding susceptibility based on El-Shamy's approach. Equally, sub-basins nos. 10 and 12 are ranked under low flooding susceptibility based on the morphometric ranking method and El-Shamy's method $\left(R_{b}\right.$ vs. $\left.F_{s}\right)$, and of moderate flooding probability based on El-Shamy's approach $\left(R_{b}\right.$ vs. $\left.D_{d}\right)$. It can be concluded that $47 \%$ (8 sub-basins) of the total can be categorized under high flooding potentiality based on the morphometric ranking method, and El-Shamy's method. Consequently, they are considered the highly hazardous sub-basins within W. Yutum watershed. It is obvious that the most hazardous sub-basin found is Yutum El-Umran (no. 8)which is developed in the basement rocks (granite)with an area of $770.95 \mathrm{~km}^{2}$ (17.5\% of the total area). Furthermore, sub-basin no. 1, which is located on sedimentary carbonate rocks, and descending from the Ras En Naqb escarpment, and lower W. Yutum are considered hazardous as well. Flash floods here are mostly attributed to these sub-basins. As a result, the Amman-Aqaba highway and the alluvial fan of W. Yutum which accommodates substantial residential areas, and major infrastructure facilities are seriously exposed to flash floods. Therefore, the protection of the city from disastrous flooding is essential to maintain future sustainable development.

Repetitive flash floods can be of great advantage if appropriate dams constructed at the narrowest sections of W. Yutum and Yutum El-Umran to retain water to reduce flow velocity and to enhance recharge in the alluvial fan of W. Yutum. Dams can be constructed by utilizing available local weathering products in the form of loose materials and boulders and deposits of fluvial terrace of W. Yutum. An earlier field survey of sediment sources across areas surrounding the back road of Aqaba revealed the occurrence of large boulder fields to the west of section A of the road, a few kilometers south of W. Yutum bridge. Dimensions of each dam depend on local geological and geomorphic conditions of the selected site. High potential flash floods in W. Yutum and Yutum El-Umran are expected to hold a high potential recharge of ground water towards the huge alluvial fan of W. Yutum. The residential areas and other urban services are encroaching at present across the fan surface. Al- 
though the toe part of the fan close to Qa el Dafiya is often inundated following flash floods, palm-tree plantations could be planted, and a deep well can be installed at the apex of the fan to provide water for the light industrial area north of Aqaba City. It is also possible to carry out an afforestation project in the Ras En Naqb escarpment based on a water harvesting system suitable for the dryland areas. Furthermore, a warning system is recommended for the Aqaba city to alarm officials and residents before the occurrence of a flash flood disaster.

\section{References}

[1] Golany, G. (1982) Selecting Site for New Settlements in Arid Lands: Negev Case Study. Energy and Buildings, 4, 23-41. http://dx.doi.org/10.1016/0378-7788(82)90016-0

[2] Cooke, R.U., Brunsden, D., Doornkamp, J.C. and Jones, D.K.C. (1985) Urban Geomorphology in Dry Lands. Oxford University Press, New York.

[3] Farhan, Y. (1989) Urban Planning and the Evaluation of Flood Hazard in Arid Lands of Jordan: Aqaba Case Study. In: Farhan, Y., Beheiry, S. and Abu Satat, M., Eds., Geomorphological Studies on Southern Jordan, Publication of the University of Jordan, 181-206. (In Arabic)

[4] Schick, A., Grodek, T. and Wolman, M.G. (1999) Hydrologic Process and Geomorphic Constraints on Urbanization of Alluvial Fan Slopes. Geomorphology, 31, 325-335. http://dx.doi.org/10.1016/S0169-555X(99)00085-9

[5] Cooke, R.U., Goudie, A.S. and Doornkamp, J.C. (1978) Middle East-Review and Bibliography of Geomorphological Contributions. Quarterly Journal of Engineering Geology and Hydrogeology, 11, 9-18. http://dx.doi.org/10.1144/GSL.QJEG.1978.011.01.02

[6] Doornkamp, J.C., Brunsden, D., Jones, D.K.C., Cooke, R.U. and Bush, P. (1979) Rapid Geomorphological Assessment for Engineering. Quarterly Journal of Engineering Geology and Hydrogeology, 12, 189-209. http://dx.doi.org/10.1144/GSL.QJEG.1979.012.03.06

[7] Golany, G. (1993) Planning Principles of Arid-Zone Settlements. Habitat International, 7, 147-163. http://dx.doi.org/10.1016/0197-3975(83)90042-5

[8] Potter, K.W. and Frevert, D.K., Eds. (2010) Proceedings of Watershed Management 2010: Innovations in Watershed Management under Land Use and Climate Change. Madison, 23-27 August 2010, American Society of Civil Engineers. http://dx.doi.org/10.1061/9780784411438

[9] Peng, S.H., Shieh, M. and Fan, S. (2010) Potential Hazard Map for Disaster Prevention Using GIS Base Linear Combination Approach and Analytic Hierarchy Method. Journal of Geographic Information System, 4, 403-411. http://dx.doi.org/10.4236/jgis.2012.45046

[10] Grodek, T., Lekack, J., and Schick, A. (2000) Urbanizing Aluvial Fans as Flood-Conveying and Flood-Reducing Systems: Lessons from the October 1997 Eilat Flood. In: Hassan, M., Ed., The Hydrology-Geomorphology Interface: Rainfall, Floods, Sedimentation, Land Use, International Association of Hydrological Sciences Publication, No. 261, 229-250.

[11] El-Shamy, I. (1992) Recent Recharge and Flash Flooding Opportunities in the Eastern Desert, Egypt. Annals of Geological Survey of Egypt, 18, 323-334.

[12] Youssef, A.M., Pradhan, B., and Hassan, A.M. (2011) Flash Flood Risk Estimation Along the St. Katherine Road, Southern Sinai, Egypt Using GIS Based Morphometry and Satellite Imagery. Environmental Earth Sciences, 62, 611-623. http://dx.doi.org/10.1007/s12665-010-0551-1

[13] Arnous, O., Aboulela, A. and Green, R. (2011) Geo-Environmental Hazards Assessment of the North Western Gulf of Suez, Egypt. Journal of Coastal Conservation, 15, 37-50. http://dx.doi.org/10.1007/s11852-010-0118-z

[14] Abdel-Lattif, A. and Sherief, Y. (2012) Morphometric Analysis and Flash Floods of Wadi Sudr and Wadi Wardan, Gulf of Suez, Egypt: Using Digital Elevation Model. Arabian Journal of Geosciences, 5, 181-195. http://dx.doi.org/10.1007/s12517-010-0156-8

[15] Abdalla, F., El-Shamy, I., Bamousa, A., Mansour, A., Mohamed, A. and Tahoon, M. (2014) Flash Floods and Groundwater Recharge Potentials in Arid Land Alluvial Basins, Southern Red Sea Coast, Egypt. International Journal of Geosciences, 5, 971-982. http://dx.doi.org/10.4236/ijg.2014.59083

[16] Abduladheem, A., Elmewafey, M., Beshr, A. and Elnaggar, A.A. (2015) Using GIS Based Morphometry Estimation of Flood Hazard Impacts on Desert Roads in South Sinai, Egypt. International Journal of Scientific and Engineering Research, 6, 1593-1599.

[17] Redwan, M., Abdel Moneim, A., Abo Amra, M. and Youssef, A. (2015) Watershed Characteristics and Flood Hazard, Assessment of the Area West of Sohag, Upper Egypt. International Journal of Environmental Engineering Research, 4, 18-26.

[18] Elmoustafa, A. and Mohamed, M. (2013) Flash Flood Risk Assessment Using Morphological Parameters in Sinai Pe- 
ninsula. Open Journal of Modern Hydrology, 3, 122-129. http://dx.doi.org/10.4236/ojmh.2013.33016

[19] Rakhi, B., Aditi, B., Catherine, B., Osama, H., Alejandra, L. and Sahar, S. (2014) Natural Disasters in the Middle East and North Africa: A Regional Overview. The World Bank, Washington DC.

[20] Murphy, B. (2010) Hydrologic Analysis for a Hyper-Arid Region in the Middle East. In: Potter, J. and Frevert, D., Eds., Proceedings of Watershed Management 2010: Innovations in Watershed Management under Land Use and Climate Change, 23-27 August 2010, Madison, 1238-1247. http://dx.doi.org/10.1061/41143(394)111

[21] Farhan, Y. and Anbar, A. (2014) Fragile Landscape: Impact and Consequences of May 2014 Flash-Flood Disaster in the Aqaba Area, Southern Jordan. Research Journal of Environmental and Earth Sciences, 6, 451-465.

[22] Al Saud, M. (2009) Morphometric Analysis of Wadi Aurnah Drainage System Western Arabian Peninsula. The Open Hydrology Journal, 3, 1-10.

[23] Hamdi, M.R., Abu Allaban, M., Al Shayeb, A., Jaber, M. and Momani, N.M. (2009) Climatic Change in Jordan. American Journal of Environmental Sciences, 5, 58-68. http://dx.doi.org/10.3844/ajessp.2009.58.68

[24] Al-Qinna, M., I., Hammouri, N.A., Obeidat, M.M, and Ahmad, F.Y. (2011) Drought Analysis in Jordan under Current and Future Climates. Climatic Change, 106, 421-440. http://dx.doi.org/10.1007/s10584-010-9954-y

[25] Ministry of Municipal and Rural Affairs (1981) Master Plan for Aqaba and South Coast. Ministry of Municipal and Rural Affairs, Amman.

[26] Aqaba Region Authority (1987) Flood Analysis Report for the Aqaba Basin: Wadi Flood Control Study. Amman.

[27] Aqaba Special Economic Zone Authority (2010) Disaster Risk Management Profile for the Aqaba. Special Economic Zone, Amman.

[28] Schick, A. (1971) A Desert Flood: Physical Characteristics, Effect on Man, Geomorphic Significance, Human Adaptation: A Case Study in the Southern Arava Watershed. Jerusalem Studies in Geography, 2, 91-155.

[29] Central Water Authority. Hydrologic Division (1966) Floods in Southern Jordan on 11 March 1966. Unpublished Report, Amman.

[30] Farhan, Y. (1999) Geomorphic Impacts of Highway Construction, their Causes and Remedies: A Case Study from Aqaba, Southern Jordan. Arab World Geographer, 2, 1-25.

[31] Farhan, Y. (2014) Geomorphological Evaluation for Urban Development Using Remote Sensing and GIS, Southern Coast of Aqaba, Jordan. Journal of Environmental and Earth Sciences, 3, 104-118.

[32] Saleh, A.S. (1989) Flash Floods in Deserts. A Geomorphic Study of Desert Wadis. Special Studies Series, Vol. 51, Institute of Arab Research, Cairo, Egypt, 1-93.

[33] Horton, R. (1945) Erosional Development of Streams and Their Drainage Basins, Hydrological Approach to Quantitative Morphology. Geological Society of America Bulletin, 56, 275-370. http://dx.doi.org/10.1130/0016-7606(1945)56[275:EDOSAT]2.0.CO;2

[34] Strahler, A. (1952) Dynamic Basis of Geomorphology. Geological Society of America Bulletin, 63, 923-938. http://dx.doi.org/10.1130/0016-7606(1952)63[923:DBOG]2.0.CO;2

[35] Strahler, A. (1957) Quantitative Analysis of Watershed Geomorphology. Transactions American Geophysical Union, 38, 913-920. http://dx.doi.org/10.1029/TR038i006p00913

[36] Strahler, A. (1964) Quantitative Geomorphology of Drainage Basins and Channel Networks. In: Chow, V., Ed., Handbook of Applied Hydrology, McGraw Hill, New York, 439-476.

[37] Smith, K. (1950) Standards for Grading Textures of Erosional Topography. American journal of Science, 248, 655-688. http://dx.doi.org/10.2475/ajs.248.9.655

[38] Miller, V. (1953) A Quantitative Geomorphic Study of Drainage Basin Characteristics in the Clinch Mountain Area, Virginia and Tennessee. Project NR 389-402, Technical Report 3, Department of Geology, ONR, Columbia University, New York.

[39] Schumm, S. (1956) Evolution of Drainage Systems and Slopes in Badlands at Pert Amboy, New Jersey. Geological Society of America Bulletin, 67, 597-646. http://dx.doi.org/10.1130/0016-7606(1956)67[597:EODSAS]2.0.CO;2

[40] Morisawa, M.E. (1959) Relation of Quantitative Geomorphology to Stream Flow in Representative Watersheds of the Appalachian Plateau Province. Project NR 389-042, Technical Report 20, Department of Geology, ONR, Columbia University, Geography Branch, New York.

[41] Abraham, A. (1984) Channel Networks: A Geomorphological Perspective. Water Resources Research, 20, 141-168. http://dx.doi.org/10.1029/wr020i002p00161

[42] Gardiner, V. (1990) Drainage Basin Morphometry. In: Goudie, A., Ed., Geomorphological Techniques, Unwin Hyman, London, 71-81.

[43] Patton, P.C. (1988) Drainage Basin Morphometry and Floods. In: Baker, V., Kochel, R. and Patton, P., Eds., Flood 
Geomorphology, Wiley, New York, 51-65.

[44] Franklin, S. (1987) Geomorphometric Processing of Digital Elevation Model. Computer \& Geosciences, 13, 603-609. http://dx.doi.org/10.1016/0098-3004(87)90030-6

[45] Kamp, U., Bolch, T. and Olsenholler, J. (2005) Geomorphometry of Cerro Sillajhauy (Andes, Chile/Bolivia): Comparison of Digital Elevation Models (DEMs) from ASTER Remote Sensing Data and Contour Maps. Geocarto International, 20, 23-33. http://dx.doi.org/10.1080/10106040508542333

[46] Ozdemir, H. and Bird, D. (2009) Evaluation of Morphometric Parameters of Drainage Networks Derived from Topographic Maps and DEM in Point of Floods. Environmental Geology, 56, 1405-1415. http://dx.doi.org/10.1007/s00254-008-1235-y

[47] Apaydin, H., Ozturk, F., Murden, H. and Aziz, N. (2006) Determination of the Drainage Basin Characteristics Using Vector GIS. Nordic Hydrology, 37, 129-142.

[48] Prasannakumar, V., Vijith, H. and Geetha, N. (2013) Terrain Evaluation through the Assessment of Geomorphometric Parameters Using DEM and GIS: Case Study of Two Major Sub-Watersheds in Attapady, South India. Arabian Journal of Geosciences, 6, 1141-1151. http://dx.doi.org/10.1007/s12517-011-0408-2

[49] Singh, P., Thakur, J. and Singh, U. (2013) Morphometric Analysis of Morar River Basin, Madhya Pradesh, India, Using Remote Sensing and GIS Techniques. Environmental Earth Sciences, 68, 1967-1977. http://dx.doi.org/10.1007/s12665-012-1884-8

[50] Markose, V., Dinesh, A. and Jayappa, K. (2014) Quantitative Analysis of Morphometric Parameters of Kali River Basin, Southern India, Using Bearin Azimuth and Drainage (bAd) Calculator and GIS. Environmental Earth Sciences, 72, 2887-2903. http://dx.doi.org/10.1007/s12665-014-3193-x

[51] Youssef A.M., Pradhan, B., Gaberr, A.F.D. and Buchroithner, M.F. (2009) Geomorphological Hazard Analysis along the Egyptian Red Sea Coast between Safaga and Quseir. Natural Hazard and Earth System Science, 9, 751-766. http://dx.doi.org/10.5194/nhess-9-751-2009

[52] Hassan, O. (2000) Salient Geoenvironmental Parameters of Ras Malaab-Abu Zenima Area, Gulf of Suez, Egypt, with an Emphasis on Flash Flood Potential and Mitigative Measures. Egyptian Journal of Remote Sensing and Space Science, 3, 37-58.

[53] Al-Saud, M. (2010) Assessment of Flood Hazards of Jeddah Area 2009, Saudi Arabia. Journal of Water Resources and Protection, 2, 839-847. http://dx.doi.org/10.4236/jwarp.2010.29099

[54] El Maghraby, M., Masoud, M. and Niyazi, B. (2014) Assessment of Surface Runoff in Arid, Data Scarce Regions; An Approach Applied to Wadi Al-Hamd, Al Madinah Al Munawarah, Saudi Arabia. Life Science Journal, 11, 271-289.

[55] Davis, J.C. (1975) Statistics and Data Analysis in Geology. Wiley, New York.

[56] Zaineldeen, U. (2013) Mapping the Dyke Swarms of the Neoproterozoic Basement in Southwestern Jordan Using Remote Sensing and GIS Techniques. Earth Science Research, 2, 156-164.

[57] Burdon, D. (1959) Handbook of the Geology of Jordan. Benham and Co., Colchester.

[58] Bender, F. (1974) Geology of Jordan. Gebrueder Borntraeger, Berlin. (Translated from the German Edition Geologie von Joradnien of 1968)

[59] Natural Resources Authority (1976) Medium Grained Alkali Granites of the Aqaba-Quweira Area for Use as a Source of Feldspar of Ceramics. Unpublished Report Geological Survey and Bureau of Mines, Natural Resources Authority, Amman.

[60] Van den Boom, G. and Lahloub, M. (1964) Geological and Petrological Investigations of the Igneous Rocks in the Area of Quweira, Southern Jordan. Unpublished Report, Natural Resources Authority, Amman.

[61] Abed, A.M. (1985) On the Supposed Precambrian Paleostructure along the Dead Sea Rift, Jordan. Journal of the Geological Society of London, 142, 527-531. http://dx.doi.org/10.1144/gsigs.142.3.0527

[62] Osborn, G. and Duford, J.M. (1981) Geomorphological Processes in the Inselberg Region of South-Western Jordan. Palestine Exploration Quarterly, 112, 1-17. http://dx.doi.org/10.1179/peq.1981.113.1.1

[63] Osborn, G. (1985) Evolution of the Late Cenozoic Inselberg landscape of Sothern Jordan. Paleogeography, Paleoclimatiology, Paleoecology, 49, 1-23. http://dx.doi.org/10.1016/0031-0182(85)90002-1

[64] Goudie, A., Migon, P., Allison, R. and Rosser, N. (2002) Sandstone Geomorphology of the Quwayra Area of South Jordan. Zeitschrift fur Geomorphologie, 46, 365-390.

[65] Saqqa, W. and Attallah, M. (2013) Tectonic Geomorphology of Alluvial Fans East of the Wadi Araba Fault (Dead Sea Transform) Jordan. Jordan Journal of Earth and Environmental Sciences, 5, 79-86.

[66] Lloyd, J.W. (1969) The Hydrology of the Southern Desert of Jordan. UNDP/FAO, Investigations of the Sandstone Aquifers of East Jordan, Technical Report No. I. 
[67] Heimbach, W. and Meiser, P. (1969) Geoelectrical Investigation in Jordan. Bundesanstalt fur Bodenforschung, Hannover.

[68] Schick, A. (1974) Alluvial Fans and Desert Roads: A Problem in Applied Geomorphology, Abhandlungen, Akademie der Wissenschaften in Gottingen. Journal of Mathematical Physics, 29, 418-425.

[69] Sharon, D. (1972) The Spottiness of Rainfall in a Desert Area. Journal of Hydrology, 17, 161-175. http://dx.doi.org/10.1016/0022-1694(72)90002-9

[70] Shehadeh, N. (1990) The Climate of Jordan. Dar Albasheir Publications, Amman.

[71] Borga, M. Boscolo, P., Zanon, F. and Sangati, M. (2007) Hydrometeorolgical Analysis of the 29 August 2003 Flash Flood in the Eastern Italian Alps. Journal of Hydrometeorology, 8, 1049-1067. http://dx.doi.org/10.1175/JHM593.1

[72] Rusjan, S., Kobold, M. and Mikos, M. (2009) Characteristics of the Extreme Rainfall Event and Consequent Flash Floods in W Slovenia in September 2007. Natural Hazards and Earth Systems, 9, 947-956. http://dx.doi.org/10.5194/nhess-9-947-2009

[73] Roca, M. and Davison, M. (2010) Two Dimensional Model Analysis of Flash-Flood Processes: Application to the Boscastle Event. Journal of Flood Risk Management, 3, 63-71. http://dx.doi.org/10.1111/j.1753-318X.2009.01055.X

[74] Arghius, V., Ozunu, A., Samara, I. and Rosian, G. (2014) Results of the Post-Flood Disaster Investigations in the Transylvanian Depression (Romania) during the Last Decade (2001-2010). Natural Hazards and Earth System Science, 14, 535-544. http://dx.doi.org/10.5194/nhess-14-535-2014

[75] NASA’s Earth Observing Data and Information System. “EOSDIS-Data Specification”. EOSDIS-Earthdata Website. http://www.jspacesystems.or.jp/ersdac/GDEM2/E/4.html

[76] ASTER GDEM Validation Ream. “ASTER Global Digital Elevation Model Version 2 Summary of Validation Results”. https://www.jspacesystems.or.jp/ersdac/GDEM/ver2Validation/Summary GDEM2 validation report_final.pdf

[77] Safiah Yusmah, M.F. and Rodziah, H. (2014) Predicting Flow Direction of Soil Erosion Using Geographical Information System (GIS). International Journal of Soil Mechanics \& Foundation, 1, 11-13.

[78] Bender, F. (1968) Geological Map of Jordan (1:250000). Geological Survey of the Republic of Germany, Hannover.

[79] Bender, F. (1974) Explanatory Notes on the Geological Map of Wadi Araba, Jordan. Scale 1:100 000. 3 Sheets, Geologisches Jahrbuch, 13, Reihe B, Heft 10, Hannover, 62 p.

[80] Bender, F. (1975) Geology of the Arabian Peninsula: Jordan. United States Geological Survey Professional Paper 450-I.

[81] Abdel Hamid, G. (1990) The Geology of Jebl Umm Ishrin Area (Wadi Rum), Natural Resources Authority (NRA), Amman, 14, 76 p.

[82] Strahler, A. (1958) Dimensional Analysis Applied to Fluvially Eroded Landforms. Geological Society of America Bulletin, 69, 279-299. http://dx.doi.org/10.1130/0016-7606(1958)69[279:DAATFE]2.0.CO;2

[83] Hadley, R. and Schumm, S. (1961) Sediment Sources and Drainage Charactristics in Upper Cheyenne River Basin. US Geological Survey Water-Supply Paper 1531-B, Washington DC, 198.

[84] Pradhan, B. (2010) Flood Susceptible Mapping and Risk Area Estimation Using Logistic Regression, GIS and Remote Sensing. Journal of Spatial Hydrology, 9, 1-18.

[85] Beheiry, S. (1972) Desert Landscape in Southern Jordan. Journal of the Faculty of Arts (University of Jordan, Amman), 3, 5-31. 